See discussions, stats, and author profiles for this publication at: https://www.researchgate.net/publication/333942066

\title{
Deciphering the Sardic (Ordovician) and Variscan deformations in the Eastern Pyrenees, SW Europe
}

Article in Journal of the Geological Society · June 2019

DOI: $10.1144 /$ jgs $2019-057$

CITATIONS

0

4 authors, including:

Claudia Puddu

University of Zaragoza

3 PUbLiCATIONS 4 CITATIONS

SEE PROFILE

DA Josep Maria Casas

University of Barcelona

87 PUBLICATIONS 722 CITATIONS

SEE PROFILE

Some of the authors of this publication are also working on these related projects:

Project Inversion Tectonics in the Alpine Foreland (Eastern Alps, Austria) View project

3D Discrete Fracture Network Modelling from Virtual Outcrop Models and Field data View project
READS

50

Núria Carrera

University of Barcelona

43 PUBLICATIONS 320 CITATIONS

SEE PROFILE 


\section{Journal of the Geological Society \\ Deciphering the Sardic (Ordovician) and Variscan deformations in the Eastern Pyrenees, SW Europe \\ --Manuscript Draft--}

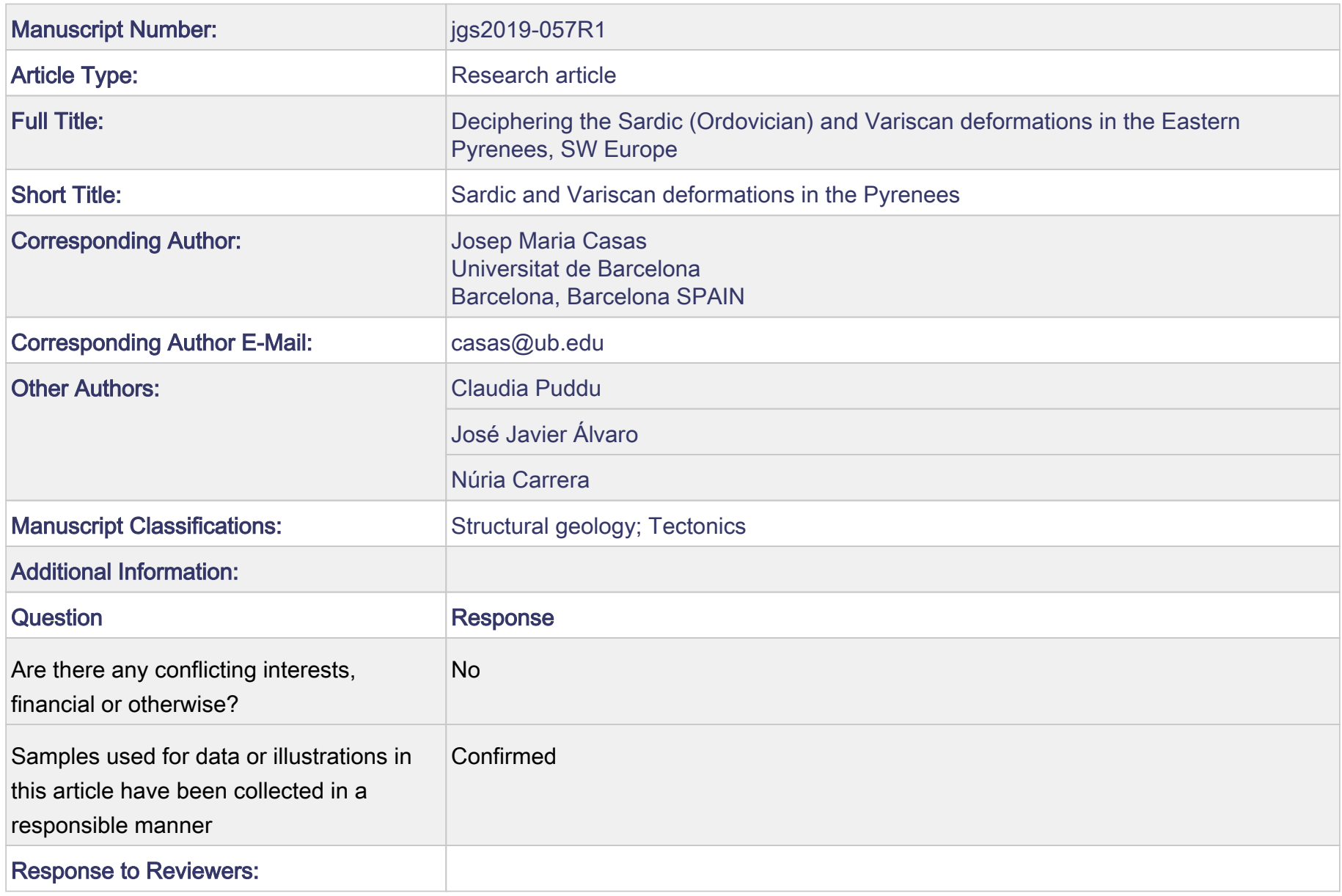




\section{Deciphering the Sardic (Ordovician) and Variscan deformations in the Eastern Pyrenees, SW Europe}

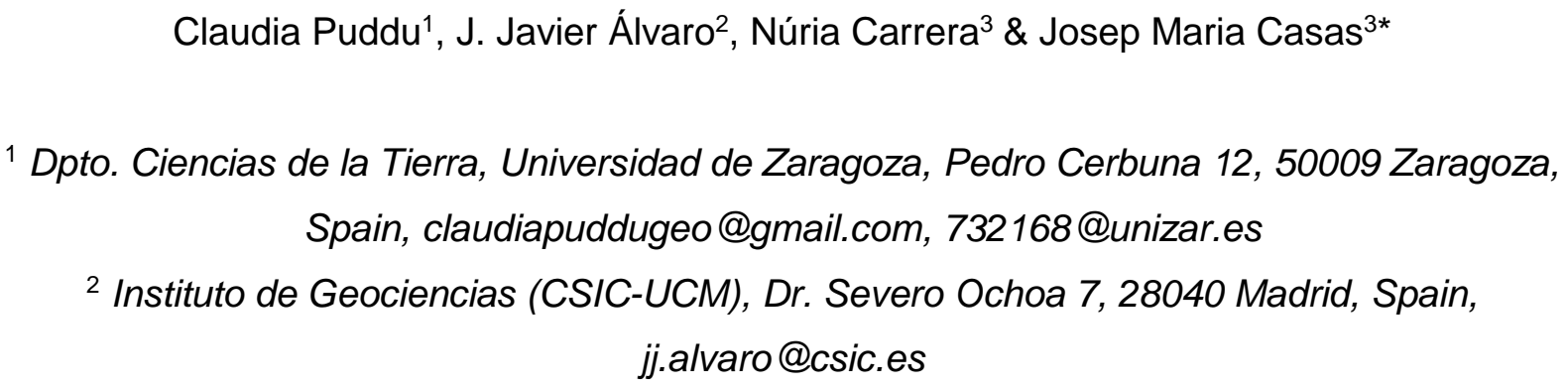

* Corresponding author (e-mail: casas@ub.edu)

Abstract: Detailed geological mapping of the La Cerdanya area (Canigó unit, Eastern Pyrenees) provides new data characterizing the different structural styles exhibited by Cambrian-Lower Ordovician (Jujols Group) and Upper Ordovician successions. Their unconformable contact, related to the Sardic Phase, ranges from $0^{\circ}$ (paraconformity) to $90^{\circ}$ (angular discordance). The Jujols Group rocks topped by the unconformity are affected by Sardic foliation-free open folds. The pre-Sardic succession, the Sardic Unconformity and the lower part of the post-Sardic succession (Rabassa Conglomerate and Cava formations) are cut and offset by several Late Ordovician NNE-SSW-trending synsedimentary extensional faults associated with hydrothermal activity, which dramatically affected the thickness of the lower part of the Upper Ordovician succession. We relate (i) the Mid-Ordovician Sardic uplift and erosion, and (ii) a Mid-Late Ordovician upward propagating extensional fault system bounding the outline of half-grabens, subsequently infilled by alluvial deposits, to a thermal doming event (about 475-450 Ma) that led to the uplift and stretching of the Ordovician lithosphere. Thermal doming may be caused by mafic magma underplating and responsible for the coeval calcalkaline magmatic activity broadly developed in the Eastern Pyrenees. We discuss the similarities between the Mid-Ordovician Sardic Unconformity and other Early Palaeozoic unconformities described in neighbouring areas. Finally, we suggest a geodynamic scenario in which a regional-scale thermal event was related to the opening of the Rheic Ocean that led to the drift of Avalonia from the SW-European margin of Gondwana.

\section{Introduction}


The Pyrenees are a WNW-ESE trending Alpine fold and thrust belt that contains pre-Variscan basement rocks, late Neoproterozoic-to-Carboniferous in age (Fig. 1). The pre-Variscan basement forms a large strip in the core of the cordillera and provides evidence of Cadomian, Sardic and Variscan magmatic episodes (Cocherie et al. 2005; Castiñeiras et al. 2008; Casas et al. 2010, 2015; Navidad et al. 2010; Pereira et al. 2014; Martínez et al. 2016; Padel et al. 2018a), and Variscan and Alpine deformation events (Guitard 1970; Zwart 1979; Muñoz 1992). The onset and significance of the Ordovician deformation has been matter of debate since the pioneer work of Llopis Lladó (1965). After Santanach (1972), it is widely accepted that the Upper Ordovician succession unconformably overlies either the Cambrian-Lower Ordovician Jujols Group or the Ediacaran-Terreneuvian Canaveilles Group (García-Sansegundo \& Alonso 1989; Den Brok 1989; Kriegsman et al. 1989; Poblet 1991; Muñoz \& Casas 1996; GarcíaSansegundo et al. 2004; Casas \& Fernández 2007). However, the origin of this unconformity has been object of several interpretations. Santanach (1972) in the Canigó massif and GarcíaSansegundo et al. (2004) in the Garona dome attributed the unconformity to basement tilting, related to a Late Ordovician faulting episode and subsequent erosion. In the Lys-Caillaouas massif, Den Brok (1989) and Kriegsman et al. (1989) proposed the existence of a pre-Variscan deformation event. A pre-Late Ordovician folding episode has been also suggested as related to the unconformity on the southern Canigó massif (Casas 2010; Casas et al. 2012). However, the geodynamic significance of this deformation episode is not yet well established: it is related neither to metamorphism nor cleavage development, although it seems related to uplift, widespread emersion and considerable erosion before the onset of Upper Ordovician deposition (Casas 2010). As a result, the Upper Ordovician rocks onlap a palaeorelief formed by different pre-Upper Ordovician formations, ranging from the upper Neoproterozoic to the Lower Ordovician in the Central and Eastern Pyrenees (Santanach 1972; Laumonier \& Guitard 1986; Cirés et al. 1994). This intra-Ordovician unconformity may be interpreted as equivalent to the "Sardic Phase" described in Sardinia (Teichmüller 1931; Stille 1939), which separates the Cambrian-Ordovician from the Upper Ordovician successions (Pillola et al. 2008).

In this paper we present new data on the structural style exhibited by the Cambrian-Ordovician and Upper Ordovician successions of the La Cerdanya area, in the Eastern Pyrenees. The data provide clear evidence of well-expressed Ordovician deformations in the form of extensional faults and folds, the latter only affecting the Cambrian-Ordovician succession. The interpretation of these pre-Variscan deformation structures should contribute to a better understanding of the origin and meaning of the Sardic Unconformity, and thus, to discuss the geodynamic setting of this fragment of North Gondwana during Ordovician times, bracketed between the Cadomian and Variscan orogenies.

\section{Geological setting}


The study area crops out in the southern flank of the Canigó Unit, which represents an antiformal Alpine structure with exposures ranging in age from Late Neoproterozoic to Carboniferous-(Fig. 1). The Alpine floor thrust of this unit is the Orri thrust (Muñoz 1992).

In the study area (Fig. 2), the Cambrian-Lower Ordovician succession consists of a thick package (ca. $1500 \mathrm{~m}$ ) of grey to greenish shales alternating with subsidiary $\mathrm{cm}$-scale sandstone interbeds. This succession represents the Serdinya Formation (Padel et al. 2018b) of the Jujols Group (Laumonier 1988). Acritarchs recovered from the uppermost part of this succession, close to the Sardic Unconformity at La Molina locality (Fig. 1) (southern slope of the Canigó massif), indicate a Furongian-earliest Ordovician age (Casas \& Palacios, 2012). This age is coincident with a maximum depositional age of ca. $475 \mathrm{Ma}$ for the uppermost part of the Jujols Group in the La Rabassa dome, on the basis of the youngest detrital zircon population (Margalef et al. 2016). To the east, in the Albera massif, metapelites and metapsammites from the uppermost part of a metasedimentary succession that can be correlated with the Jujols Group are crosscut by acidic subvolcanic dykes, which constrain its minimum depositional age to 465-472 Ma (Liesa et al. 2011). All these data suggest a depositional age for the uppermost part of the Jujols Group at ca. $475 \mathrm{Ma}$. On the other hand, a ca. $455 \mathrm{Ma} \mathrm{U}-\mathrm{Pb}$ age for the Upper Ordovician volcanic rocks directly overlying the Sardic Unconformity has been proposed in the Eastern Pyrenees (Martí et al. 2014), in the Les Gavarres (455 $\pm 1.8 \mathrm{Ma}$, Navidad et al. 2010) and Les Guilleries (452 \pm 4 Ma, Martínez et al. 2011) areas. This suggests a time gap of about 20 m.y. for the Sardic Phase in the Pyrenees, similar to the gap found in SW Sardinia, the type area where the original unconformity was described; there, the unconformity separates the Cambrian-Ordovician from the Upper Ordovician successions, marking a stratigraphic gap of ca. 18 m.y. that includes part of the Floian (Pillola et al. 2008), the entire Dapingian and Darriwilian, and part of the Sandbian (Hammann 1992; Leone et al. 2002).

In the Eastern Pyrenees, the overlying Upper Ordovician succession (Cavet 1957; Hartevelt 1970) forms a broad fining-upward siliciclastic package that comprises some limestone key levels and displays significant thickness variations, ranging from 100 to $1000 \mathrm{~m}$ (Fig. 3). This succession was originally described by Hartevelt (1970), who distinguished five formations; i.e. from base to top, the Rabassa Conglomerate, Cava, Estana, Ansobell and Bar Quartzite formations. The Rabassa Conglomerate Formation, up to $100 \mathrm{~m}$ thick, consists of reddishpurple, polygenic conglomerates with heterometric clasts composed of quartzite and slate derived from underlying rocks and vein quartz. The overlying Cava Formation, $0-850 \mathrm{~m}$ thick, is

111 made up of conglomerates, sandstones and shales with volcanic intercalations; one coquina 112 punctuating their shale interbeds have yielded brachiopods (Svobodaina havliceki, Rostricellula 113 sp. and Rafinesquina sp.) and bryozoans, suggesting a Katian (former late Caradoc-early 
114 Ashgill) age (Hartevelt 1970; Gil-Peña et al. 2004; Puddu \& Casas 2011). The Estana

115 Formation, 5-200 m thick, is composed of limestone and marly limestone rich in brachiopods,

116 bryozoans, echinoderms and conodonts of late Katian age (Gil-Peña et al. 2004). The top of the

117 carbonate succession is unconformably capped by the black-grey shales of the Hirnantian

118 Ansobell Formation, 20-320 m thick, which in turn is overlain by the Bar Quartzite, 2-20 m thick

119 and dated as Hirnantian on the basis of their fossiliferous content (Sanz López \& Sarmiento

120 1995; Sanz López et al. 2002; Roqué Bernal et al. 2017; Štorch et al. 2018).

121

122 In several areas of the Pyrenees, from Pierrefite to the west (Calvet et al. 1988) to the Ribes de

123 Freser area to the east (Robert \& Thiebaut 1976; Robert 1980; Ayora 1980; Martí et al. 2014)

124 volcanic rocks have been reported interbedded in the Upper Ordovician sediments. These

125 volcanic rocks consist of pyroclastic deposits with subsidiary lavas and subvolcanic intrusive

126 rocks (Martí et al. 1986, 2019). They include andesite, rhyodacite and rhyolite that make up a

127 small fraction of the corresponding Ordovician. Additionally, the Ribes area includes a

128 subvolcanic granitic body, the Ribes granophyre, emplaced in the lower part of the Sandbian-

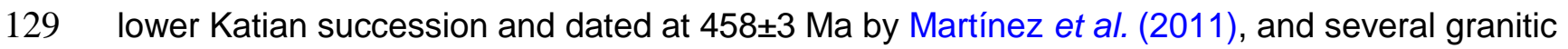

130 orthogneissic bodies emplaced in the lower part of the pre-Variscan succession (the Núria

131 gneiss with a protolith age of $457 \pm 4 \mathrm{Ma}$, Martínez et al. 2011; and the Queralbs gneiss, with a

132 protolith age of $457 \pm 5 \mathrm{Ma}$, Martínez et al. 2011).

133

134 All these pre-Variscan rocks display a polyphase deformation linked to the Variscan

135 deformation and a low-pressure/high-temperature metamorphism (Guitard 1970; Zwart 1979). A

136 pervasive foliation is the main deformational structure in the medium- to high-grade

137 metasediments and the gneissic bodies derived from Ordovician and Cadomian granitoids. This

138 foliation $\left(\mathrm{S}_{1-2}\right)$ is a composite fabric developed prior to coeval with the Variscan regional

139 metamorphism, being associated with an E-W to NE-SW oriented stretching lineation. $\mathrm{S}_{1-2}$ is

140 folded by later E-W to NW-SE upright folds, forming the mesostructure that depicts the Aston-

141 Hospitalet, Canigó, Roc de Frausa and Albera gneissic domes all along the backbone of the

142 chain. According to Clariana \& García-Sansegundo (2009) and García-Sansegundo et al.

143 (2011), in the Garona dome and the Pallaresa massif, $S_{1}$ is a slaty cleavage only developed in

144 the Cambro-Ordovician succession and not related to folds; and $\mathrm{S}_{2}$ is associated with N-verging

145 recumbent folds formed at Carboniferous time. In the eastern part of Pallaresa massif (central

146 Pyrenees), south of Aston massif and north of the Tor-Casamanya syncline, Clariana et al.

147 (2009) and Clariana \& García-Sansegundo (2009) described a subvertical $S_{3}$ crenulation

148 cleavage, axial plane of $\mathrm{E}-\mathrm{W}$ trending upright folds, deforming $\mathrm{S}_{1-2}$. This $\mathrm{S}_{3}$ becomes the main

149 cleavage in the Pallaresa massif, the Tor-Casamanya and Llavorsí synclines and the Rabassa

150 and Orri domes (Speksnijder 1986; Poblet 1991; Clariana \& Sansegundo 2009; Margalef \&

151 Casas 2016). $\mathrm{S}_{3}$ exhibits a fan-like attitude close to the southern contact with the post-Variscan 
152

153

154

155

156

157

158

159

160

161

162

163

164

165

166

167

168

169

170

171

172

173

174

175

176

177

178

179

180

181

182

183

184

185

186

187

188

189

rocks due to the Alpine rotations linked to thrust sheet stacking (Muñoz 1992) The Devonian and the Carboniferous Culm rocks of the study area exhibit a well-developed cleavage that can be correlated with this $S_{3}$ mesostructure (Martín-Closas et al. 2018). Additionally, to the south of the study area, several thrust sheets involving Devonian and Carboniferous rocks can be observed (Hartevelt 1970; Domingo et al. 1988; Casas et al. 1989; Martín-Closas et al. 2018).

Their basal detachment is located at the base of the Silurian black shales; although most of the thrusts are south-directed, some north-directed thrusts can be observed. In the southern limb of the $D_{3}$ megastructures, as the Rabassa dome, thrusts and the lower detachment dip to the south. In turn, thrusts cut the fold-related cleavage. Thus, thrust development in the postSilurian rocks must have been broadly coeval with the onset of $D_{3}$ folds in the low-grade preSilurian rocks (Martín-Closas et al. 2018). In the Eastern and Central Pyrenees this deformation episode occurred at 330-319 Ma, according to the age of syn-orogenic Carboniferous Culm deposits (latest Visean to Serpukhovian by Sanz-López et al. 2006; Namurian by Delvolvé 1981; Delvolvé \& Perret 1989; Delvolvé et al. 1993; Martín-Closas et al. 2018). This age is coincident with the maximum deposition ages of $336 \pm 2$ and $356 \pm 9 \mathrm{Ma}$ obtained from $\mathrm{U}-\mathrm{Pb}$ on detrital zircon from Carboniferous rocks (Martínez et al. 2016). A minimum age, in turn, is provided by the age of the crosscutting Andorra-Montlluís granodiorite, dated as $305 \pm 3$ Ma by Romer \& Soler (1995), 305 \pm 5 Ma by Maurel et al. (2004), and 301.5 \pm 1.9 Ma by Pereira et al. (2014).

\section{Structure}

We performed a detailed (1:5,000 scale) geological map of the Talltendre area and measured a stratigraphic log of the Upper Ordovician succession cropping out along the road near Ordén village (Fig. 2). This study area constitutes the WNW-ESE oriented vertical-to-subvertical southern flank of the Canigó antiform that joins southwards with a synformal megastructure, where Silurian, Devonian and pre-Variscan Carboniferous successions are extensively exposed (Fig. 1). Together with this subvertical arrangement, excellent outcrop conditions allow the recognition of the Sardic Unconformity, a system of extensional faults and several deformation mesostructures chronologically subdivided into three different episodes. To better visualize and reconstruct the fault geometry, cartographic data were integrated into a 3D environment (MOVE software), which also facilitated the geometric analysis of the Sardic Unconformity.

\section{Sardic Unconformity}

The Cambrian-Lower Ordovician outcrops are onlapped, at angles ranging from a few to $90^{\circ}$, by both the Rabassa conglomerate and the Cava formations (Figs 2-4). The angular 
190 discordance separates the Upper Ordovician succession on its southern side from underlying

191 Cambrian-Ordovician strata on its northern side. This contact shows a planar to weakly

192 undulated, locally irregular surface capping the Cambrian-Ordovician strata, and can be

193 considered as an unconformity laterally ranging from a paraconformity to an angular

194 discordance. The unconformity exhibits a roughly WNW-ESE trend (194/75) although, locally,

195 the orientation ranges from E-W to NW-SE (Fig. 5a-b).

196

197 The Upper Ordovician succession shows a NW-SE trend of vertical to subvertical strata. Upper

198 Ordovician beds may be either overturned or strongly dipping northwards or dip eastwards in

199 the eastern part of the study area (Fig. 6). In contrast, Cambrian-Ordovician bedding surfaces

200 exhibit a wide range of orientations (see below).

201

202

Polyphase folding

203

204

The most visible mesostructures of the Cambrian-Ordovician and Upper Ordovician rocks are bedding surfaces. Field data show that bedding surfaces exhibit different orientations (Fig. 7). Orientation of the Cambrian-Ordovician succession presents a marked dispersion and dip values ranging from subvertical to subhorizontal (Fig. 7a). In contrast, the Upper Ordovician bedding poles exhibit a more regular NW-SE trend (Fig. 7b). As we will discuss below, the marked dispersion of the bedding poles in Cambrian-Ordovician strata suggests the superposition of several fold systems. In the description that follows, $L_{1}$ and $L_{3}$ refer to different fold axes, and $\mathrm{L}_{0-2}$ and $\mathrm{L}_{0-3}$ to bedding/cleavage intersection lineation.

$D_{1}$ structures. The existence of $D_{1}$ folds can be inferred from the arrangement of bedding surfaces at outcrop and different map scales, and from the pattern displayed by $D_{3}$ linear elements, intersection lineations and fold axis in the Cambrian-Ordovician sequence. That is,

$216 D_{3}$ folds developed over initially non-horizontal surfaces and $D_{1}$ folds control the geometry of $D_{3}$

217 mesoscale folds (e.g., Turner \& Weiss 1963: p. 130; Mey 1967: p. 194; Ramsay 1967: p. 539).

218 The existence of previous $D_{1}$ folds may also explain the distribution of $D_{2}$ mesostructures on the 219 Cambrian-Ordovician rocks. Concerning the initial orientation of $D_{1}$ fold axes, the map analysis suggests that: (i) despite dispersion, Cambrian-Ordovician bedding exhibits two maxima in their orientations at WNW-ESE and NE-SW (Fig. 7a); (ii) WNW-ESE orientations predominate over NE-SW ones; and (iii) especially interesting are the outcrops in which the Cambrian-Ordovician beds are NE-SW oriented, and are both vertical and normal to the unconformity horizon (Fig.

224 8a). In such a situation, after unfolding the Upper Ordovician sequence using WNW-ESE

225 horizontal rotational axis parallel to the Upper Ordovician unconformity, the NE-SW vertical

226 Cambrian-Ordovician beds still remain vertical and with a similar NE-SW orientation (Fig. 8b).

227 This observation suggests that $D_{1}$ fold axes presented an initial subhorizontal NE-SW 
orientation, with a short limb oriented NE-SW subvertical or strongly dipping, and a long limb subhorizontal or gently dipping towards the SE or NW. However, the effect of superposed $D_{3}$ folds precludes to assess whether $D_{1}$ folds have a NW or SE vergence. Analysis of the areas where subvertical WNW-ESE and NE-SW orientations coexist allows the estimation of 10 to 100 m-scale dimensions of $D_{1}$ folds (Fig. 9). It should be noted that there is no evidence of an axial planar cleavage development or other mesostructrures related to $D_{1}$ fold formation.

$D_{2}$ structures. A not very pervasive cleavage $\left(S_{2}\right)$ is observable at outcrop scale in the Cambrian-Ordovician rocks, while $S_{2}$ is well developed in the fine fraction of the Upper Ordovician, being deflected by coarser deposits (such as conglomerates and sandstones), where it develops irregularly. $S_{2}$ surfaces generally dip $20^{\circ}$ to $80^{\circ}$ towards the E-ENE (Fig. $7 \mathrm{c}-$ d) and are commonly deformed by $D_{3}$ folds. In the Upper Ordovician rocks, $S_{2}$ exhibits dispersion along a N-S oriented girdle (Fig. 7d). Neither folds nor other mesostructures related to this event have been clearly identified in the field. $A s D_{3}$ linear mesostructures, $L_{0-2}$ exhibits a wider dispersion in the pre- than in the post-unconformity rocks (Fig. 7c-d).

$D_{3}$ structures. A north-dipping $S_{3}$ cleavage is the dominant deformation structure recognizable in the exposures of the study area. $S_{3}$ cleavage is observable from outcrop down to microscopic scale, and is correlated with the dominant cleavage observed in the Silurian and Devonian rocks cropping out to the south of the area. $S_{3}$ is oriented NW-SE with variable dips towards the NE. In the eastern area, it is subvertical or strongly dipping, whereas in the western sector it dips gently to moderately towards the NE (Fig. 2).

$S_{3}$ is related to $D_{3}$ folds affecting both the pre- and post-unconformity rocks. As the $S_{3}$ surfaces, the $D_{3}$ fold axial surfaces are generally gently dipping $\left(10^{\circ}-45^{\circ}\right)$ towards the N-NE in the western part of the study area, while to the east they have the same orientation, though steeply dipping or subvertical. $D_{3}$ folds are SW vergent, open to tight and generally 1-100 m scale with $\mathrm{cm}$-scale minor folds (2nd or 3rd order folds) on the limbs of the main folds. $D_{3}$ folds show mildly curved hinges that generally developed harmonic folding, especially in the Upper Ordovician rocks. $D_{3}$ fold axes exhibit different orientations in the pre- and post-unconformity rocks (Fig. 7ef). In the Upper Ordovician succession, $L_{3}$ axes and $L_{0-3}$ intersection lineations are grouped forming a maximum with a moderate plunge to the WNW or ESE (Fig. 7f). The bedding/cleavage relationship indicates that the study area constitutes the southern flank of a south-facing first-order $\mathrm{D}_{3}$ fold oriented WNW-ESE (Fig. 2b).

In contrast, the minor $L_{3}$ axes and $L_{0-3}$ intersection lineations of the Cambro-Ordovician rocks display a wide range of orientations. $\mathrm{L}_{0-3}$ plunge ranges from sub-horizontal to $45^{\circ}$ (Figs. $7 \mathrm{e}$ ), and no simple distribution pattern may be deduced from map analysis (Fig. 2). If $L_{0-3}$ and $L_{3}$ are 
266 plotted together, they are mainly distributed along a great circle coincident with the $\mathrm{S}_{3}$ average

267 plane, although two maxima oriented ca. 20-40\%/000 and $25 \% / 115$, respectively, can be

268 envisaged with predominance of low plunge values (Fig. 7e).

Extensional faults and tectonically induced sedimentation

At the map scale, several extensional faults affecting the Cambrian-Ordovician strata, the

273 Sardic unconformity and the lowermost part of the Upper Ordovician succession can be

274 recognized (Figs 2-5) (Casas \& Fernández 2007; Casas 2010). At present, the faults trend

275 broadly N-S to NNE-SSW, and their hangingwall generally appears to be the eastern block,

276 despite the presence of some antithetic faults (Fig. 2). The faults are steep, domino-style and

277 their surface dips range from $48^{\circ}$ to $90^{\circ}$ towards the WNW and ESE. This variation in orientation

278 together with the changes in strike along a fault plane detected in $3 \mathrm{D}$ analysis suggest that the

279 faults are slightly folded around a subhorizontal NNE-SSW axis (189/00) (Fig. 5c). Maximum

280 throws vary between 200 and $750 \mathrm{~m}$. The NNE-SSW fault orientation could have prevented the

281 inversion of the faults during the Variscan and Alpine deformation events, but the orientation did

282 not prevent their rotation following horizontal E-W axes during the former events. The faults are

283 associated with synsedimentary hydrotermal activity, represented by dense networks of quartz

284 veins encased in the uppermost part of the Jujols Group and subparallel to the trace of the

285 extensional faults. These served as source for huge amounts of vein quartz clasts that form the

286 Rabassa conglomerate (Fig. 10 a-b).

288 The displacement of some of these faults diminishes progressively up-section and vanishes in

289 the upper part of the Upper Ordovician rocks, especially in the lower part of the Cava

290 Formation, indicating that the faults became inactive before deposition of the overlying Estana

291 strata (Fig. 2). Thus, the Rabassa Conglomerate and the lower part of the Cava formations are

292 syn-tectonic sediments, whereas the upper part of the Cava Formation and the overlying

293 Estana, Ansobell and Bar formations are post-tectonic sediments. As a result, the whole Upper

294 Ordovician succession shows sharp changes in total thickness ranging between $190 \mathrm{~m}$ and 900

$295 \mathrm{~m}$, with a general increase from $\mathrm{W}$ to $\mathrm{E}$. Perpendicular to these faults, the Rabassa

296 Conglomerate Formation displays sharp changes in thickness (from 0 to $100 \mathrm{~m}$ ) and facies

297 associations. Deposits of the Rabassa Conglomerate Formation neighbouring the extensional

298 faults consist of chaotic breccias ranging both laterally and vertically to matrix- to clast-

299 supported conglomerates (Fig. 11d-e). These include massive to weakly stratified, unsorted,

300 pebble-dominated deposits of sandstone, shale, vein quartz and mafic phenocrysts (Fig. 11a-b).

301 Contacts are commonly scoured and grading is both normal and inverse. Breccias and matrix-

302 supported conglomerates show either chaotic or amalgamated patterns; they interfinger laterally

303 with packages of clast-supported conglomerates and pebbly sandstones that pinch out or 
304 change abruptly, both laterally and vertically, into sandstone/shale alternations (Cava

305 Formation). Clast-supported conglomerates show massive to weakly imbricated pebbles and

306 cobbles (Fig. 11f), subrounded, moderately sorted and grade upsection and laterally into

307 litharenites; the latter display centimetre- to decimetre-scale trough and low-angle cross-

308 stratified sets alternating with shales (Fig. 11g), irregularly burrowed. Lithostratigraphycally, the

309 occurrence of shale interbeds marks the base of the Cava Formation. Three facies associations

310 can be recognized: (i) Breccias and matrix-supported conglomerates are interpreted as having

311 undergone different types of downslope transport by basal sliding of plastic to semi-rigid

312 sediment masses that included contemporaneous hydrothermal dykes of quartz (Fig. 11e).

313 Amalgamation of debris-flow deposits indicates the presence of neighbouring slopes close to

314 synsedimentary extensional faults. (ii) Packages of clast-supported conglomerates and pebbly

315 sandstones represent in-channel gravel bars that graded into straight to sinuous crested

316 bedforms in shallow, braided systems. During high-discharge events, sediments were reworked

317 and accumulated as channelized conglomerates. (iii) Finally, sandstone/shale alternations

318 reflect the influence of marine shoreface-to-offshore conditions with local development of

319 burrowing by soft-bodied metazoans

It should be noted that as the Upper Ordovician unconformity is cut by these normal faults, significant pre-Upper Ordovician erosive processes took place preceding the normal faulting 323 event.

Synsedimentary faults are planar, either non-rotational or with small amounts of rotation affecting the beds in the hangingwall. The geographical distribution of these normal faults allows subdivision of the Upper Ordovician succession into six domains (Fig. 6). In the four western domains $\left(A_{1}\right.$ to $\left.A_{4}\right)$, the Upper Ordovician bedding planes exhibit an E-W or NW-SE trending orientation, ranging from N100E to N120E with subvertical or strongly dipping attitude. In domain $A_{5}$, the Upper Ordovician bedding planes exhibit a wider range of dipping values, with bedding poles distributed in a NE-SW girdle, as a result of a 119/28 oriented fold axis (Fig. 6). In the easternmost domain $A_{6}$, the Upper Ordovician bedding planes show a roughly NW-SE trending with variable dipping as a result of a 115/16 oriented fold axis. The divergence between the beds next to the hangingwall varies between a minimum value of $10^{\circ}\left(A_{5}\right)$ and a maximum of $24^{\circ}\left(A_{4}\right)$, with a main value of $18^{\circ}\left(A_{2}\right)$ and $20^{\circ}\left(A_{3}\right)$, which allows us to infer a ca. $20^{\circ}$ fault rotation.

338 It is difficult to identify the faults as well as to recognize an eventual detachment horizon in the 339 Cambrian-Ordovician rocks. This and the steep arrangement of the fault surfaces preclude an 340 estimate of the amount of extension linked to fault movements. In any case, the small amount of 341 bed rotation in the hangingwall of the faults, ca. 20, indicates a small amount of E-W extension. 


\section{Discussion}

344 Structure: age and significance of folds $D_{1}, D_{2}$ and $D_{3}$

$346 D_{1}$ folds affecting the Cambrian-Ordovician succession are sealed by Upper Ordovician strata.

347 Thus, it is assumed that the episode $D_{1}$ is earlier than the successions deposited above. An

348 Early-Mid Ordovician age can be proposed for this folding event. Moreover, $D_{1}$ fold axes are

349 parallel to subparallel to the direction of the Late Ordovician extensional faults. We noted the

350 absence of microscale $D_{1}$ folds and the lack of either associated cleavage or metamorphism.

351 We interpret that $D_{1}$ folds can form at the hangingwall blocks of extensional faults. Folds related

352 to extensional faults have been extensively described, caused by slip on nonplanar normal

353 faults (Xiao \& Suppe 1992), on faults with ramp-flat-ramp fault geometry (Rotevatn \& Jackson

354 2014), on localized zone of shortening between two fault trends (Abu Sharib et al. 2017) or as

355 fault-propagation folds (Sharp et al. 2000). From these possibilities, we favour that $D_{1}$ folds

356 formed as fault-propagation folds of upward-propagating normal faults. In this situation, vertical

357 or steeply dipping pre-Sardic beds in the hangingwall near the fault surface are common as

358 propagation of the fault tip to the surface results in breaching of a previous fold (Sharp et al.

359 2000). Therefore, two possibilities can be envisaged: either the fold formation is linked to pre-

360 Sardic (Early-Mid Ordovician) movements of the mapped extensional faults, or they resulted

361 from the movement of other extensional faults, not detected in the area due to the monotonous

362 character of the Cambrian-Ordovician succession and the lack of cartographic marker beds.

363 According to the first possibility, post-Sardic (Late Ordovician) upward fault propagation should

364 led to normal faults cutting previous folds, the topographic surface and the unconformity, and

365 post-Sardic sediments filling the hangingwalls thinning away from fault surfaces (Fig. 2).

366 According to the second option, the faults would not reach the topographic surface, and normal

367 faults would rest as blind faults in the pre-Sardic sequence. In any case, the Upper Ordovician

368 unconformity changes from a paraconformity in the long limb of the $D_{1}$ folds or in the footwall of

369 the faults, to an angular unconformity in the hinge zone or in the vertical limbs of the $D_{1}$ folds in

370 the hangingwall of the faults (Fig. 9). As stated before, the outcrop conditions, together with the

371 monotonous character and the lack of cartographic key levels in the pre-Sardic sequence,

372 make it difficult to identify these blind faults as well as the continuation in the pre-unconformity

373 sequence of the normal faults cutting the unconformity. The situation depicted above argues

374 against a contractional origin for the Ordovician (Sardic) folds in the Pyrenees as previously

375 proposed by Casas (2010) and Casas et al. (2012).

377 Equivalent $D_{1}$ pre-main cleavage folds were described by Casas (2010) to the north of the 378 Canigó unit, in the El Conflent area, and more to the east, in the La Molina area. The former 379 exhibit a similar N-S direction with axes strongly dipping to the north, whereas in the La Molina, 
380 pre-main cleavage folds are mainly oriented NNW-SSE. As in the study area, the combination

381 of both pre-main cleavage folds and syn-foliation folds with variable orientations gives rise to a

382 complex disposition of bedding planes (Casas 2010).

384 The interpretation of the deformation episode $D_{2}$ is more difficult due to the lack of related

385 mesostructures. It could be correlated with the $\mathrm{S}_{2}$ cleavage associated with $\mathrm{N}$-verging

386 recumbent folds described in the Garona and Pallaresa domes by Clariana \& García-

387 Sansegundo (2009) and Clariana et al. (2009). However, the lack of related folds in the study

388 area makes this correlation speculative. In any case, the age of this deformation should be

389 post-Ordovician (Variscan) because it affects both the pre- and post-unconformity deposits.

391 The main foliation $\left(S_{3}\right)$ recognized in the study area can be correlated with the pervasive axial

392 plane crenulation cleavage $\left(\mathrm{S}_{3}\right)$ of $\mathrm{E}-\mathrm{W}$ trending upright folds, which represents the main

393 cleavage preserved in the Pallaresa massif, the Tor-Casamanya and Llavorsí synclines and the

394 Rabassa and Orri domes (Speksnijder 1986; Poblet 1991; Clariana \& Sansegundo 2009;

395 Margalef \& Casas 2016). It should be noted that the Cambrian-Ordovician succession of these

396 Pyrenean massifs shares a common structural arrangement: a regional crenulation cleavage,

397 regularly oriented and dipping to the north, associated with intersection lineations and minor fold

398 axes displaying a significant dispersion. This arrangement, described for example in the

399 Rabassa dome (Poblet 1991; Capellà \& Bou 1997), the Massana anticline (Hartevelt 1970;

400 Poblet 1991; Casas et al. 1998), the Orri dome (Hartevelt 1970; Speksnijder 1986; Poblet 1991)

401 and the Lys-Caillaouas massif (Den Brok 1989), among others, has been attributed to the

402 presence of pre-foliation (pre- $\mathrm{D}_{3}$ ) deformations.

403

404 Origin of the Sardic Unconformity, extensional faults and D1 folds

405

406

The angular unconformity described above represents the prolongation of those described

407 westwards by Casas \& Fernández (2007), and in the La Molina area by Santanach (1972) and

408 Casas (2010). The unconformity can be attributed to the doming, tilting and erosion of a pre-

409 Sardic succession, which preceded the deposition of the Upper Ordovician conglomerates and

410 sandstones (Santanach 1972; García-Sansegundo et al. 2004). Doming, tilting and truncation of

411 Cambrian-Ordovician strata suggest relative uplift, perhaps associated with a fall in the eustatic

412 sea level.

414 The Sardic Unconformity was affected by a Late Ordovician extensional pulsation, responsible

415 for the movement of the NNE-SSW oriented normal faults that led to the contemporaneous

416 opening of grabens and half-grabens. These were infilled with the alluvial, fluvial and volcano-

417 sedimentary deposits of the Upper Ordovician Rabassa Conglomerate and Cava formations, 
418 which also reflected a significant and stepwise hydrothermal activity. Simultaneously, a Late

419 Ordovician magmatic pulse yielded a varied suite of magmatic rocks: small granitic bodies are 420 emplaced in the pre-unconformity strata of the Canigó massif and constitute the protoliths of the 421 Cadí, Casemí, Núria and Canigó G-1 type gneisses (ca. 457-446 Ma, Casas et al. 2010;

422 Martínez et al. 2011; Navidad et al. 2018), together with metre-scale thick bodies of metadiorite 423 (ca. $453 \mathrm{Ma}$, Casas et al. 2010). Coeval calc-alkaline volcanic rocks (ignimbrites, andesites and 424 volcaniclastic rocks) are interbedded in the Upper Ordovician of the Ribes de Freser area 425 (Robert \& Thiébaut 1976; Ayora 1980; Robert 1980; Martí et al. 1986, 2019); a granitic body at 426 Ribes with granophyric texture, dated at ca. 458 Ma by Martínez et al. (2011), intrudes at the 427 base of the Upper Ordovician succession. Metre-scale rhyodacitic to dacitic subvolcanic sills 428 intercalated within the pre-unconformity succession close to the base of the Upper Ordovician 429 have also yielded Late Ordovician ages in the La Pallaresa dome (ca. $453 \mathrm{Ma}$, Clariana et al. 430 2018).

432 Previously, a Floian-Dapingian magmatic pulse, coeval with the uplift and subsequent 433 extensional activity related to $D_{1}$ fold formation took place. This pulse gave rise to the intrusion 434 of voluminous peraluminous granites, about 500 to $3000 \mathrm{~m}$ thick and emplaced into the pre435 unconformity strata. They constitute the protoliths of the large laccolith-shaped, orthogneissic 436 bodies that punctuate the backbone of the Pyrenees, from west to east, the Aston (ca. 470-467 437 Ma, Denèle et al. 2009; Mezger \& Gerdes 2016), Hospitalet (ca. 472 Ma, Denèle et al. 2009), 438 Canigó (ca. 472-462 Ma, Cocherie et al. 2005; Navidad et al. 2018), Roc de Frausa (ca. 477439476 Ma, Cocherie et al. 2005; Castiñeiras et al. 2008) and Albera (ca. 470 Ma, Liesa et al. 440 2011) massifs. As a whole, the Ordovician magmatism in the Pyrenees lasted about 30 m.y., 441 from ca. 477 to $446 \mathrm{Ma}$, a time span contemporaneous with the Ordovician deformations 442 described above (Fig. 12).

Taken all together, uplift, denudation, extensional tectonics and magmatic activity may be related to a thermal doming caused by the underplating of hot mafic magmas (Fig. 13). This scenario has been invoked as the origin of the Furongian-Early Ordovician magmatism in the Central Iberian Zone of the Iberian Massif related to the so-called Toledanian Phase (Bea et al. 2007; Montero et al. 2009; Díez Montes et al 2010). The latter is characterized by a Furongian gap associated with the onset of a remarkable magmatic activity of calc-alkaline affinity, giving rise to the the Ollo de Sapo and Urra formations, ca. 495-470 Ma (see summaries in Álvaro et al. 2007; García-Arias et al. 2018; Casas \& Murphy 2018; ,Sánchez-García et al., in press). In the Pyrenees, doming would start at ca. $475 \mathrm{Ma}$, causing regional uplift and emersion responsible for the end of the marine Jujols Group sedimentation, its erosion and the emplacement of a widespread calc-alkalline granitic magmatism (Fig. 13). Subsequent extensional episodes would be related to the opening of half-grabens and their infill with the 
Rabassa Conglomerate Formation and the lower part of the Cava Formation. The latter sedimentation was coeval with magmatic activity until ca. $450 \mathrm{Ma}$, when thermal relaxation led to marine transgression and sedimentation (middle part of the Cava Formation) that onlapped an inherited Sardic-related palaeorelief. After a glaciogenic transgression represented by the blanketing of the basin by the Ansobell Formation, isostatic rebound at ca. 445 Ma may be signalled by the progradation of the Bar Quartzite Formation, coincident with the end of the magmatic activity and with the final sealing of inherited Sardic palaeotopographies at Silurian times. Later on, the Variscan deformation would overprint all these rocks and structures at Mid Carboniferous times.

\section{Comparison with neighbouring areas}

In Sardinia, the Sardic Unconformity is associated with an intra-Ordovician stratigraphic gap in the autochthonous Palaeozoic basement of the Iglesiente-Sulcis area (southwestern Sardinia), which corresponds to the External Zone of the South-European Variscan Chain. Similar gaps (named Sarrabese Unconformity) are found in the External nappe Zone, associated with coeval igneous activities in the Sarrabus-Gerrei area ( 465 Ma: Buzzi et al. 2007a, 2007b; Oggiano et al. 2010). The post-unconformity succession is related to Upper Ordovician magmatism in SW Sardinia ( 457 Ma: Pavanetto et al. 2012) and central-northern Sardinia ( 469 Ma up to 456 Ma: Helbing \& Tiepolo 2005; Giacomini et al. 2006; Boriani 2008). Indeed, in Sardinia, the preSardic sequence is affected by different E-W striking structures with neither regional metamorphism nor cleavage, displaying 1 to $100 \mathrm{~m}$-scale folds without cleavage and faults, subsequently sealed by Upper Ordovician strata (Pasci et al. 2008; Cocco \& Funedda 2012, 2019; Cocco et al. 2018). We can recall, for instance, the structure of the Su Scoffoni area in southeastern Sardinia, where Cocco \& Funedda (2019) described the Sardic Unconformity sealing folds affecting only the pre-Upper Ordovician succession. As a result, the Upper Ordovician succession in SE Sardinia overlies Cambrian-Ordovician beds with different attitudes, in a similar way than that described above from the Eastern Pyrenees. The occurrence of faults and the environment of half-grabens have been supposed by Brusca \& Dessau (1968) and Martini et al. (1991), who associate them with a post-unconformity deposit (Monte Argentu Formation) in SW Sardinia.

In the Occitan Domain (Mouthoumet and Montagne Noire massifs) of southern France, the Ordovician is punctuated by two major gaps: a Sardic Unconformity (ranging from paraconformable to angular discordant contacts) and a diachronous Silurian erosive unconformity that represents blanketing of an inherited glaciogenic palaeorelief (Álvaro et al. 2016). As in the case of the Eastern Pyrenees and Sardinia, the Montagne Noire includes emplacement of massive (Sardic-related) Middle Ordovician granitic bodies. The migmatitic 
494 Somail Orthogneiss of the southern Axial Zone, derived from an Ordovician metagranite that 495 was emplaced at $471 \pm 4 \mathrm{Ma}$ and $450 \pm 6 \mathrm{Ma}$ (U-Pb zircon ages; Roger et al. 2004; Cocherie et 496 al. 2005). Recent geochronological dating of these augen orthogneisses has updated the story 497 of various generations of granitoids that form the core of the Axial Zone (e.g., Cocherie 2003; 498 Roger et al. 2004; Faure et al. 2004; Bé Mézème 2005; Charles et al. 2009). A post-Sardic 499 rifting reactivation is recorded in the Mouthoumet massif and the Cabrières klippes (southern 500 Montagne Noire), where Late Ordovician fault-controlled subsidence and the record of rift501 related continental tholeiitic lavas were coeval, in some areas, with the onset of the Hirnantian 502 glaciation (Álvaro et al. 2016, 2018). Re-opening of rifting branches was followed by onlapping 503 patterns and final sealing of Sardic palaeotopographies during Silurian and Early Devonian 504 times. It led to fault-controlled subsidence and the generation of structurally controlled depocentres, at least in the Cabrières sector of the Montagne Noire and the Mouthoumet area. It was accompanied by marine transgression and extensional pulses that gradually led to flooding and onlapping on the shoulders of the rifting branches, which were finally sealed during 508 Early Devonian times.

As a result, the Sardic Phase is shared by the Occitan Domain, the Eastern Pyrenees and 511 Sardinia, all of them located along the eastern branch of the Variscan Ibero-Armorican Arc 512 during Ordovician times. According to some authors (e.g., Stampfli et al. 2002), this margin of 513 Gondwana faced the Proto-Tethys, also called Ran Ocean (Torsvik \& Cocks 2009), and later on 514 the Palaeo-Tethys Ocean (Torsvik \& Cocks 2004; Von Raumer \& Stampfli 2008). This geodynamic setting is different to that faced by the Iberian Massif, located along the western branch of the Ibero-Armorican Arc. In the Central Iberian and Ossa-Morena Zones of the Iberian Massif, a similar but earlier unconformity, the Toledanian unconformity is represented by an angular discordance that separates variably tilted Ediacaran-Cambrian Series 2 rift-related successions from an overlying Tremadocian-Floian passive-margin succession. The involved

520 gap (at least 22 m.y) includes, at least, most of the Furongian and basal Ordovician, although 521 the erosion can incise into the entire Cambrian and the upper Ediacaran Cadomian basement (Gutiérrez Marco et al. 2002). The Toledanian Phase has been recently interpreted (Sánchez-

523 García et al. 2008) as representing the rift/drift transition that led to the opening of the Rheic 524 Ocean (Díez Montes et al. 2010; Thomson et al. 2010; Nance et al. 2010; Álvaro et al. 2014, 2018; Casas et al. in press). Neither metamorphism nor penetrative deformation related to this unconformity have been described, except in the Marão Anticline and the Amêndoa-Carvoeiro

527 Synform of the Central-Iberian Zone. In these areas, cleavage-bearing folds with steep axial 528 planes at high angles to Variscan structures have been described and related to transient 529 compression and dextral strike-slip features along the Central-Iberian/Ossa-Morena contact 530 lineament (Romão \& Ribeiro 1993; Correia Romão et al. 2005; Romão et al. 2005, 2013; 531 Amaral et al. 2014). A similar volcanic-free "Furongian gap" related to a break-up unconformity 
532 has been reported in the central Anti-Atlas of Morocco, and related to the above-reported

533 Toledanian Phase (Álvaro \& Vizcaïno 2018).

The magmatism associated with the Toledanian and Sardic Phases is dominantly felsic and calc-alkaline, and exhibits an arc-like signature that some authors have interpreted as linked to subduction conditions (Castro et al. 2002; Del Greco et al. 2016). However, other authors have interpreted this signature as an inherited character caused by the fast melting of a subductionrelated Neoproterozoic crust (Díez Montes et al. 2010; Navidad et al. 2010; Sánchez-García et al. in press). This fast melting may also explain the great amount of inherited zircons, the highly porphyritic character and the virtual absence of mafic bodies in these magmas. These may have resulted from the partial melting of granitoids or sediments in the continental lower crust caused by the underplating or intrusion of hot mafic magmas that produced a great heat input during an extensional event (Bea et al. 2007; Montero et al. 2009; Díez Montes et al. 2010).

\section{Conclusions}

In the Eastern Pyrenees, the Sardic unconformity separates two successions with different structural features. The Cambrian-Lower Ordovician and the Upper Ordovician succession are affected by Late Ordovician extensional tectonics and by two Variscan deformation events. Moreover the Cambrian-Lower Ordovician succession is also affected by an Early-Mid Ordovician fold system that we relate to extensional faults. Upward propagation of some of these extensional faults during Sandbian-Katian times, caused that faults affect the Sardic Unconformity and the lowermost part of the Upper Ordovician succession.

We relate the extensional fault formation to a thermal doming developed between 475 and 450 Ma. The doming should have produced stretching of the Ordovician lithosphere, together with emersion, uplift and erosion of the Cambrian-Ordovician sequence giving rise to the formation of the Sardic Unconformity. Thermal doming may be also responsible of coeval magmatic activity well developed in the same area and caused by hot mafic magma underplating. We compare the Mid Ordovician Sardic unconformity in the Pyrenees with contemporaneous gaps recognized in Sardinia and the Occitan Domain, and also discuss the similarities with the

563 Furongian Toledanian gap described in the neighbouring Iberian Massif, which may have been originated in similar scenarios.

We suggest a regional-scale thermal event ranging in age from Early-Mid to Late Ordovician, which affected several areas of the Northern Gondwana margin. Their role in the geodynamic scenario that originated other significant Early Palaeozoic events, as the opening of the Rheic 
569 Ocean and the drift of Avalonia (sensu lato) from the western part of North Gondwana, has to 570 be investigated.

571

572 Acknowledgements

573

574 We acknowledge the use of MOVE (Midland Valley) and Stereonet (R. W. Allmendinger) 575 software packages and financial support provided by CGL2015-66335-C2-1-R and CGL2017576 87631-P projects from Spanish MINECO. Detailed reviews by R. Vissers and an anonymous 577 referee greatly improved a first version of the manuscript.

578 


\section{References}

Abu Sharib, A. S. A. A., Abdel-Fattah, M. M., Salama, Y. F. \& Abdel-Gawad, G. I. 2017. Extension-related buttress-like folds, the western side of the Gulf of Suez rift, Egypt. International Journal of Earth Sciences, 106, 2527-2547.

Álvaro, J. J. \& Vizcaïno, D. 2018. The Furongian break-up (rift-drift) transition in the Anti-Atlas, Morocco. Journal of Iberian Geology, 44, 567-587.

Álvaro, J. J., Ferretti, F., González-Gómez, C., Serpagli, E., Tortello, M. F., Vecoli, M. \& Vizcaïno, D. 2007. A review of the Late Cambrian (Furongian) palaeogeography in the western Mediterranean region, NW Gondwana. Earth-Science Reviews, 85, 47-81.

Álvaro, J. J., Bellido F., Gasquet D., Pereira F., Quesada C. \& Sánchez-García T. 2014. Diachronism in the late Neoproterozoic-Cambrian arc-rift transition of North Gondwana: A comparison of Morocco and the Iberian Ossa-Morena Zone. Journal of African Earth Sciences, 98, 113-132.

Álvaro, J. J., Colmenar, J., Monceret, E., Pouclet, A. \& Vizcaïno, D. 2016. Late Ordovician (post-Sardic) rifting branches in the North-Gondwanan Montagne Noire and Mouthoumet massifs of southern France. Tectonophysics, 681, 111-123.

Álvaro, J. J., Casas J. M., Clausen S. \& Quesada C. 2018. Early Palaeozoic geodynamics in NW Gondwana. Journal of Iberian Geology, 44, 551-565.

Amaral, A., Dias, R., Coke, C., Romão, J. \& Ribeiro, A. 2014. Fase de deformação sarda na Zona Centro-lbérica. Comunicações Geológicas, 101, 239-242.

Ayora C. 1980. Les concentrationes metàl-liques de la Vall de Ribes. PhD, Barcelona University.

Bé Mézème, E. 2005. Contribution de la géochronologie U-Th-Pb sur monazite à la compréhension de la fusion crustale dans la chaîne Hercynienne française et implication géodynamique. PhD, Orléans University.

Bea, F., Montero, P., González Lodeiro, F. \& Talavera, C. 2007. Zircon inheritance reveals exceptionally fast crustal magma generation processes in Central Iberia during the Cambro-Ordovician. Journal of Petrology, 48, 2327-2339. 
617

618

619

620

621

622

623

624

625

626

627

628

629

630

631

632

633

634

635

636

637

638

639

640

641

642

643

644

645

646

647

648

649

650

651

652

653

Boriani, A. 2008. Age and origins of the Italian continental crust: data and interpretations. Rendiconti online della Società Geologica Italiana, Abstracts, 3, 124.

Brusca, C. \& Dessau, G. 1968. I giacimenti piombo-zinciferi di S.Giovanni (Iglesias) nel quadro della geologia del Cambrico sardo. L'Industria Mineraria, 19, 470-494, 533-556, 597609.

Buzzi, L., Funedda, A., Gaggero, L. \& Oggiano G. 2007a. Sr-Nd isotope, trace and REE element geochemistry of the Ordovician volcanism in the southern realms of the Variscan belt. EGU General Assembly 2007, Wien, 15-20 April 2007, Abstracts.

Buzzi, L., Gaggero, L., Funedda, A., Oggiano, G. \& Tiepolo, M. 2007b. Zircon geochronology and $\mathrm{Sr} / \mathrm{Nd}$ study of the Ordovician magmatic events in the southern Variscides (Sardinia). Géologie de la France, 2, 73.

Calvet, Ph., Lapierre H. \& Charvet J. 1988. Diversité du volcanisme ordovicien dans la région de Pierrefitte (Hautes-Pyrénées): rhyolites calco-alcalines et basaltes alcalins. Comptes Rendus de l'Académie des Sciences, Paris, 307 (série 2), 805-812.

Capellà, I. \& Bou, O. 1997. La estructura del domo de la Rabassa y del sector oriental del sinclinal de Llavorsi (Pirineo central). Estudios Geológicos, 53, 121-133.

Casas, J. M. 2010. Ordovician deformations in the Pyrenees: new insights into the significance of pre-Variscan ('sardic') tectonics. Geological Magazine, 147, 674-689.

Casas, J. M. \& Fernández, O. 2007. On the Upper Ordovician unconformity in the Pyrenees: New evidence from the La Cerdanya area. Geologica Acta, 5, 193-198.

Casas, J. M. \& Murphy B. 2018. Unfolding the arc: The use of pre-orogenic constraints to assess the evolution of the Variscan belt in Western Europe. Tectonophysics, 736, 4761.

Casas, J. M. \& Palacios T. 2012. First biostratigraphical constraints on the pre-Upper Ordovician sequences of the Pyrenees based on organic-walled microfossils. Comptes Rendus Géoscience, 344, 50-56. 
654 Casas, J. M., Domingo, F., Poblet, J. \& Soler, A. 1989. On the role of the Hercynian and Alpine

655

656

657

658

659

660

661

662

663

664

665

666

667

668

669

670

671

672

673

674

675

676

677

678

679

680

681

682

683

684

685

686

687

688

689

690

691 thrusts in the Upper Paleozoic rocks of the Central and Eastern Pyrenees. Geodinamica Acta, 3, 135-147.

Casas, J. M., Parés, J. M. \& Megías, L. 1998. La fábrica magnética de los materiales cambroordovícicos del Anticlinal de la Massana (Andorra, Pirineo Central). Revista de la Sociedad Geológica de España, 11, 317-329.

Casas J. M., Castiñeiras P., Navidad M., Liesa M. \& Carreras J. 2010. New insights into the Late Ordovician magmatism in the Eastern Pyrenees: U-Pb SHRIMP zircon data from the Canigó massif. Gondwana Research, 17, 317-324.

Casas J. M., Queralt P., Mencos J. \& Gratacós O. 2012. Distribution of linear mesostructures in oblique folded surfaces: Unravelling superposed Ordovician and Variscan folds in the Pyrenees. Journal of Structural Geology, 44, 141-150.

Casas, J. M., Navidad, M., Castiñeiras, P., Liesa, M., Aguilar, C., Carreras, J., Hofman, M., Gärtner, A. \& Linnemann, U. 2015. The Late Neoproterozoic magmatism in the Ediacaran series of the Eastern Pyrenees: new ages and isotope geochemistry. International Journal of Earth Sciences, 104, 909-925.

Casas, J. M., Álvaro, J. J., Clausen, S., Padel, M., Puddu, C., Sanz-López, J., Sánchez-García, T., Navidad, M., Castiñeiras, P. \& Liesa, M. (in press). Palaeozoic basement of the Pyrenees. In: Quesada, C. \& Oliveira, J. T. (eds.) The Geology of Iberia: a Geodynamic Approach. Regional Geology Reviews series. Springer, Heidelberg.

Castiñeiras P., Navidad M., Liesa M., Carreras J. \& Casas J.M. 2008. U-Pb zircon ages (SHRIMP) for Cadomian and Lower Ordovician magmatism in the Eastern Pyrenees: new insights in the pre-Variscan evolution of the northern Gondwana margin. Tectonophysics, 46, 228-239.

Castro, A., Corretgé, G., de la Rosa, J., Enrique, P., Martínez, F. J., Pascual, E. et al. 2002. Palaeozoic magmatism. In: W. Gibbons \& T. Moreno (Eds.) The Geology of Spain. The Geological Society, London, 117-153.

Cavet, P. 1957. Le Paléozoïque de la zone axiale des Pyrénées orientales françaises entre le Roussillon et l'Andorre. Bulletin du Service de la Carte géologique de France, 55, 303518. 
692

693

694

695

696

697

698

699

700

701

702

703

704

705

706

707

708

709

710

711

712

713

714

715

716

717

718

719

720

721

722

723

724

725

726

727

728

729

Charles, N., Faure, M. \& Chen, Y. 2009. The Montagne Noire migmatitic dome emplacement (French Massif Central): new insights from petrofabric and AMS studies. Journal of Structural Geology, 31, 1423-1440.

Cirés, J., Casas, J. M., Muñoz, J. A., Fleta, J. \& Barbera, M. 1994. Mapa geológico de España a escala 1:50.000, hoja de Molló (no. 218). ITGE, Madrid.

Clariana, P. \& García-Sansegundo, J. 2009. Variscan structure in the eastern part of the Pallaresa massif, Axial Zone of the Pyrenees (NW Andorra). Tectonic implications. Bulletin de la Société géologique de France, 180, 501-511.

Clariana, P., García-Sansegundo, J. \& Gavaldà, J. 2009. The structure in the Bagneres de Luchon and Andorra cross sections (Axial Zone of the central Pyrenees). Trabajos de Geología, Universidad de Oviedo, 29, 175-181.

Clariana, P., Valverde-Vaquero, P., Rubio-Ordóñez, A., Beranoaguirre, A. \& GarcíaSansegundo, J. (2018). Pre-Variscan tectonic events and Late Ordovician magmatism in the Central Pyrenees: $\mathrm{U}-\mathrm{Pb}$ age and $\mathrm{Hf}$ in zircon isotopic signature from subvolcanic sills in the Pallaresa massif. Journal of Iberian Geology, 44, 589-601.

Cocco, F. \& Funedda, A. 2012. The Variscan basement of the Riu Ollastu area (Sarrabus, SE Sardinia, Italy). Géologie de la France, 1, 89-90.

Cocco, F. \& Funedda, A. 2019. The Sardic phase: field evidence of Ordovician tectonics in SE Sardinia, Italy. Geological Magazine, 156, 25-38.

Cocco, F., Oggiano, G., Funedda, A., Loi, A. \& Casini, L. 2018. Stratigraphic, magmatic and structural features of Ordovician tectonics in Sardinia (Italy): a review. Journal of Iberian Geology, 44, 619-639.

Cocherie, A. 2003. Datation avec le SHRIMP II du métagranite oeillé du Somail-Montagne Noire. BRGM: Compte Rendu technique ANA-ISO/NT.

Cocherie, A., Baudin, T., Guerrot, C., Autran, A., Fanning, M. C. \& Laumonier, B. 2005. U-Pb zircon (ID-TIMS and SHRIMP) evidence for the early Ordovician intrusion of metagranites in the late Proterozoic Canaveilles Group of the Pyrenees and the Montagne Noire (France). Bulletin de la Société géologique de France, 176, 269-282. 
731 Correira Romão, J. M., Coke, C., Dias, R. \& Ribeiro, A. 2005. Transient inversion during the opening of the Wilson cycle "Sardic phase" in the Iberian Variscides - Stratigraphic and tectonic record. Geodinamica Acta, 18, 115-129.

Del Greco, K., Johnston, S. T. \& Shaw, J. 2016. Tectonic setting of the North Gondwana margin during the Early Ordovician: a comparison of the Ollo de Sapo and Famatina magmatic

Deloule, E., Alexandrov, P., Cheilletz, A., Laumonier, B. \& Barbey, P. 2002. In-situ U-Pb zircon ages for Early Ordovician magmatism in the eastern Pyrenees, France: the Canigou orthogneisses. International Journal of Earth Sciences, 91, 398-405.

Delvolvé, J. J. 1981. Arguments en faveur de l'âge namurien du Culm des Pyrénées Centrales françaises. Comptes Rendus de l'Académie des Sciences, Paris, 293, 219-222.

Delvolvé, J. J. \& Perret, M. F. 1989. Variations de l'âge des sédiments calcaires et "Culm" carbonifère dans la chaîne varisque du Sud de la France: migration de l'orogenèse

Delvolvé, J. J., Souquet, P., Vachard, D., Perret, M. F. \& Aguirre, P. 1993. Caractérisation d'un bassin d'avant-pays dans le Carbonifère des Pyrénées: faciès, chronologie de la tectonique synsédimentaire. Comptes Rendus de l'Académie des Sciences, Paris, 316

Den Brok, S. W. J. 1989. Evidence for pre-Variscan deformation in the Lys Caillaouas area, Central Pyrenees, France. Geologie en Mijnbouw, 68, 377-380.

Denèle Y., Barbey P., Deloule E., Pelleter E., Olivier Ph. \& Gleizes G. 2009. Middle Ordovician $\mathrm{U}-\mathrm{Pb}$ age of the Aston and Hospitalet orthogneissic laccoliths: their role in the Variscan evolution of the Pyrenees. Bulletin de la Société géologique de France, 180, 209-221.

Díez Montes, A., Martínez Catalán, J. R. \& Bellido Mulas, F. 2010. Role of the Ollo de Sapo 763 massive felsic volcanism of NW Iberia in the Early Ordovician dynamics of northern Gondwana. Gondwana Research, 17, 363-376. 
Domingo, F., Muñoz, J. A. \& Santanach, P. 1988. Estructures d'encavalcament en les materials del sòcol hercinia del massís de la Tossa d’Alp, Pirineu oriental. Acta Geológica Hispánica, 23, 141-153.

Faure, M., Ledru, P., Lardeaux, J. M. \& Matte, P. 2004. Paleozoic orogenies in the French Massif Central. A cross section from Béziers to Lyon. 32nd International Geological Congress. Field-trip Guide Book, Florence (Italy), 1-40.

García-Arias, M., Díez-Montes, A., Villaseca, C. \& Blanco-Quintero, I. F. 2018. The CambroOrdovician Ollo de Sapo magmatism in the Iberian Massif and its Variscan evolution: A review. Earth-Science Reviews, 176, 345-372.

García-Sansegundo, J. \& Alonso, J. L. 1989. Stratigraphy and structure of the southeastern Garona Dome. Geodinamica Acta, 3, 127-134.

García-Sansegundo, J., Gavaldà, J. \& Alonso, J. L. 2004. Preuves de la discordance de l'Ordovicien supérieur dans la zone axiale des Pyrénées: exemple de dôme de la Garonne (Espagne, France). Comptes Rendus Géoscience, 336, 1035-1040.

García-Sansegundo, J., Poblet, J., Alonso, J. L. \& Clariana, P. 2011. Hinterland - foreland zonation of the Variscan orogen in the Central Pyrenees: comparison with the northern part of the Iberian Variscan Massif. In: Poblet, J. \& Lisle, R. J. (eds.). Kinematic Evolution and Structural Styles of Fold-and-Thrust Belts. Geological Society of London, Special Publications, 349, 169-184

Giacomini, F., Bomparola, R. M., Ghezzo, C. \& Guldbransen, H. 2006. The geodynamic evolution of the Southern European Variscides: constraints from the U/Pb geochronology and geochemistry of the lower Palaeozoic magmatic-sedimentary sequences of Sardinia (Italy). Contributions to Mineralogy and Petrology, 152, 19-42.

Gil-Peña, I., Barnolas, A., Villas, E. \& Sanz-López, J. 2004. El Ordovícico Superior de la Zona Axial. In: Vera, J.A. (ed.) Geología de España. SGE-IGME, Madrid, 247-249.

Guitard, G. 1970. Le métamorphisme hercynien mésozonal et les gneiss œillés du massif du Canigou (Pyrénées orientales). Mémoires du BRGM, 63, 1-353. 
802

803

804

805

806

807

808

809

810

811

812

813

814

815

816

817

818

819

820

821

822

823

824

825

826

827

828

829

830

831

832

833

834

835

836

837

838

839

Gutiérrez-Marco, J. C., Robardet, M., Rábano, I., Sarmiento, G. N., San José-Lancha, M. A., Herranz Araújo, P. \& Pieren Pidal, A. P. 2002. Ordovician. In: Gibbons W. \& Moreno T. (eds.) The Geology of Spain. Geological Society, London, 31-49.

Hammann, W. 1992. The Ordovician trilobites from the lberian Chains in the province of Aragón, NE Spain. The trilobites of the Cystoid Limestone (Ashgill Series). Beringeria, 6, $1-219$.

Hartevelt, J. J. A. 1970. Geology of the upper Segre and Valira valleys, central Pyrenees, Andorra/Spain. Leidse Geologische Mededelingen, 45, 167-236.

Helbing, H. \& Tiepolo, M. 2005. Age determination of Ordovician magmatism in NE Sardinia and its bearing on Variscan basement evolution. Journal of the Geological Society, 162, 689-700.

Kriegsman, L. M., Aerden, D. G. A. M., Bakker, R. J., den Brok, S. W. J. \& Schutjens, P. M. T. M. 1989. Variscan tectonometamorphic evolution of the eastern Lys-Caillaouas massif, Central Pyrenees - evidence for late orogenic extension prior to peak metamorphism. Geologie en Mijnbouw, 68, 323-333.

Laumonier, B. 1988. Les groupes de Canaveilles et de Jujols ("Paléozoïque inférieur") des Pyrénées orientales - arguments en faveur de l'âge essentiellement Cambrien de ces séries. Hercynica, 4, 25-38.

Laumonier, B. \& Guitard, G. 1986. Le Paléozoïque inférieur de la moitié orientale de la Zone Axiale des Pyrénées. Essai de synthèse. Comptes Rendus de l'Académie des Sciences, Paris, 302, 473-478.

Leone, F., Ferretti, A., Hammann, W., Loi, A., Pillola, G. L. \& Serpagli, E. 2002. A general view on the post-Sardic Ordovician sequence from SW Sardinia. Rendiconti della Società Paleontologica Italiana, 1, 51-68.

Liesa, M., Carreras, J., Castiñeiras, P., Casas, J. M., Navidad, M. \& Vilà, M. 2011. U-Pb zircon age of Ordovician magmatism in the Albera Massif (Eastern Pyrenees). Geologica Acta, 9, 1-9.

Llopis Lladó, N. 1965. Sur le Paléozoïque inférieur de l'Andorre. Bulletin de la Société géologique de France, 7, 652-659. 
840

841

842

843

844

845

846

847

848

849

850

851

852

853

854

855

856

857

858

859

860

861

862

863

864

865

866

867

868

869

870

871

872

873

874

875

876

877

Margalef, A. \& Casas, J. M. 2016. Corte geológico compensado del sur de Andorra: aportaciones a la estructura varisca del Pirineo central. Geo-Temas, 16, 61-63.

Margalef A., Castiñeiras P., Casas J. M., Navidad M., Liesa M., Linnemann U., Hofmann M. \& Gärtner A. 2016. Detrital zircons from the Ordovician rocks of the Pyrenees: Geochronological constraints and provenance. Tectonophysics, 681, 124-134.

Martí, J., Muñoz, J. A. \& Vaquer, R. 1986. Les roches volcaniques de l'Ordovicien supérieur de la région de Ribes de Freser-Rocabruna (Pyrénées catalanes): caractères et signification. Comptes Rendus de l'Académie des Sciences, Paris, 302, 1237-1242.

Martí, J., Casas, J. M., Guillén, N., Muñoz, J. A. \& Aguirre G. 2014. Structural and geodynamic constraints of Upper Ordovician volcanism of the Catalan Pyrenees. Gondwana 15 Abstracts book, p. 104.

Martí, J., Solari, L., Casas, J. M. \& Chichorro, M. 2019. New geochronological data on the Upper Ordovician volcanism in the Eastern Pyrenees (NE Iberia): Stratigraphic and geodynamic implications. Geological Magazine, https://doi.org/10.1017/S0016756819000116.

Martín-Closas, C., Trias, S. \& Casas, J. M. 2018. New palaeobotanical data from Carboniferous Culm deposits constrain the age of the Variscan deformation in the Eastern Pyrenees. Geologica Acta, 16, 107-123.

Martínez, F., Iriondo, A., Dietsch, C., Aleinikoff, J. N., Peucat, J. J., Cirès, J., Reche, J. \& Capdevila, R. 2011. U-Pb SHRIMP-RG zircon ages and $\mathrm{Nd}$ signature of lower Paleozoic rifting-related magmatism in the Variscan basement of the Eastern Pyrenees. Lithos, 127, 10-23.

Martínez, F. J., Dietsch, C., Aleinikoff, J., Cirés, J., Arboleya, M. L., Reche, J. \& Gómez-Gras, D. 2016. Provenance, age, and tectonic evolution of Variscan flysch, southeastern France and northeastern Spain, based on zircon geochronology. Geological Society of America Bulletin, 128, 842-859.

Martini, I.P., Tongiorgi, M., Oggiano, G. \& Cocozza, T. 1991. Ordovician alluvial fan to marine shelf transition in SW Sardinia, Western Mediterranean Sea: tectonically ("Sardic phase") influenced clastic sedimentation. Sedimentary Geology, 72, 97-115. 
878

879

880

881

882

883

884

885

886

887

888

889

890

891

892

893

894

895

896

897

898

899

900

901

902

903

904

905

906

907

908

909

910

911

912

913

914

Maurel, O., Respaut, J. P., Monié, P., Arnaud, N. \& Brunel, M. 2004. U-Pb emplacement and ${ }^{40} \mathrm{Ar} /{ }^{39} \mathrm{Ar}$ cooling ages of the eastern Mont-Louis granite massif (Eastern Pyrenees, France). Comptes Rendus Geoscience, 336, 1091-1098.

Mey, P. H. W. 1967. The geology of the Upper Ribagorzana and Baliera valleys, Central Pyrenees, Spain. Leidse Geologische Mededelingen, 41, 153-220.

Mezger, J. \& Gerdes, A. 2016. Early Variscan (Visean) granites in the core of central Pyrenean gneiss domes: implications from laser ablation $\mathrm{U}-\mathrm{Pb}$ and $\mathrm{Th}-\mathrm{Pb}$ studies. Gondwana Research, 29, 181-198.

Montero, P., Talavera, C., Bea, F., Lodeiro, F. G. \& Whitehouse, M. J. 2009. Zircon geochronology of the Ollo de Sapo Formation and the age of the Cambro-Ordovician rifting in Iberia. Journal of Geology, 117, 174-191.

Muñoz J. A. 1992. Evolution of a continental collision belt: ECORS-Pyrenees crustal balanced cross-section. In: Mc Clay K.R. (ed.) Thrust Tectonics. Chapman \& Hall, London, 235246.

Muñoz, J. A. \& Casas, J. M. 1996. Tectonique préhercynienne. In: Barnolas A. \& Chiron J.C. (eds.) Synthèse Géologique et Géophysique des Pyrénées. BRGM-ITGE, OrléansMadrid, 587-589.

Nance, R. D., Gutiérrez-Alonso, G., Keppie, J. D., Linnemann, U., Murphy, J. B., Quesada, C., Strahan, R. A. \& Woodcock, N. H. 2010. Evolution of the Rheic Ocean. Gondwana Research, 17, 194-222.

Navidad, M., Castiñeiras, P., Casas, J. M., Liesa, M., Fernández-Suárez, J., Barnolas, A., Carreras, J. \& Gil-Peña, I. 2010. Geochemical characterization and isotopic ages of Caradocian magmatism in the northeastern Iberia: insights into the Late Ordovician evolution of the northern Gondwana margin. Gondwana Research, 17, 325-333.

Navidad, M., Castiñeiras, P., Casas, J. M., Liesa, M., Belousova, E., Proenza, J. \& Aiglsperger Th. 2018. Ordovician magmatism in the Eastern Pyrenees: Implications for the geodynamic evolution of northern Gondwana. Lithos, 314-315, 479-496. 
915 Oggiano, G., Gaggero, L., Funedda, A., Buzzi L. \& Tiepolo M. 2010. Multiple early Paleozoic volcanic events at the northern Gondwana margin: $\mathrm{U}-\mathrm{Pb}$ age evidence from the Southern Variscan branch (Sardinia, Italy). Gondwana Research, 17, 44-58.

Padel, M., Álvaro, J. J., Casas, J. M., Clausen, S., Poujol, M. \& Sánchez-García, T. 2018a. Cadomian volcanosedimentary complexes across the Ediacaran-Cambrian transition of the eastern Pyrenees, France and Spain. International Journal of Earth Sciences, 107, 1579-1601.

Padel, M., Clausen, S., Álvaro, J. J. \& Casas, J. M. 2018b. Review of the Ediacaran-Lower Ordovician (pre-Sardic) stratigraphic framework of the Eastern Pyrenees, southwestern Europe. Geologica Acta, 16, 339-355.

Pasci, S., Pertusati, P.C., Salvadori, I. \& Murtas A. 2008. I rilevamenti CARG del Foglio geologico 555 "Iglesias" e le nuove implicazioni strutturali sulla tettonica della "Fase Sarda". Rendiconti online della Società Geologica Italiana, Abstracts, 3, 614-615.

Pavanetto, P., Funedda, A., Northrup, C.J., Schmitz, M., Crowley, J. \& Loi A. 2012. Structure and $\mathrm{U}-\mathrm{Pb}$ zircon geochronology in the Variscan foreland of SW Sardinia, Italy. Geological Journal, 47, 426-445.

Pereira, M. F., Castro, A., Chichorro, M., Fernández, C., Díaz-Alvarado, J., Martí, J. \&

Pillola, G.L., Piras, S. \& Serpagli, E. 2008. Upper Tremadoc-Lower Arenig? AnisograptidDichograptid fauna from the Cabitza Formation (Lower Ordovician, SW Sardinia, Italy). Revue de Micropaléontologie, 51, 167-181. Rodríguez, C. 2014. Chronological link between deep-seated processes in magma chambers and eruptions: Permo-Carboniferous magmatism in the core of Pangaea

Puddu, C. \& Casas, J. M. 2011. New insights into the stratigraphy and structure of the Upper Ordovician rocks of the la Cerdanya area (Pyrenees). In: Gutiérrez-Marco J.C., Rábano I. \& García-Bellido D. (eds.) Ordovician of the World. Cuadernos del Museo Geominero, $14,441-445$. 
953

954

955

956

957

958

959

960

961

962

963

964

965

966

967

968

969

970

971

972

973

974

975

976

977

978

979

980

981

982

983

984

985

986

987

988

Ramsay, J. G. 1967. Folding and Fracturing of Rocks. Mac Graw-Hill, New York.

Robert, J. F. 1980. Étude géologique et métallogénique du val de Ribas sur le versant espagnol des Pyrénées catalanes. PhD, Franche-Comté University.

Robert, J. F. \& Thiébaut, J. 1976. Découverte d'un volcanisme acide dans le Caradoc de la région de Ribes de Freser (Prov. de Gérone). Comptes Rendus de l'Académie des Sciences, Paris, 282, 2050-2079.

Roger, F., Respaut, J. P., Brunel, M., Matte, P. \& Paquette, J. L. 2004. Première datation U-Pb des orthogneiss oeillés de la zone axiale de la Montagne Noire (Sud du Massif central): nouveaux témoins du magmatisme ordovicien dans la chaîne Varisque. Comptes Rendus Geoscience, 336, 19-28.

Romão, J. \& Ribeiro, A. 1993. Thrust tectonics of Sardic age in the Rosmaninhal area (Beira Baixa, Central Portugal). Comunicações dos Serviços Geológicos de Portugal, 78, 8795.

Romão, J., Coke, C., Dias, R. \& Ribeiro, A. 2005. Transient inversion during the opening stage of the Wilson cycle "sardic phase" in the Iberian Variscides - stratigraphic and tectonic record. Geodinamica Acta, 18, 115-129.

Romão, J., Metodiev, D., Dias, R. \& Ribeiro, A. 2013. Evolução geodinâmica dos sectores meridionais da Zona Centro-lbérica. In: Dias, R., Araújo, A., Terrinha, P. \& Kullberg, J. C. (eds.) Geologia do Portugal, 1, 206-257. Escolar Editora, Lisbon.

Romer, R. L. \& Soler, A. 1995. U-Pb age and lead isotopic characterization of Au-bearing skarn related to the Andorra granite. Mineralium Deposita, 30, 374-383.

Roqué Bernal, J., Štorch, P. \& Gutiérrez-Marco, J. C. 2017. Bioestratigrafía (graptolitos) del límite Ordovícico-Silúrico en los Pirineos orientales (curso alto del río Segre, Lleida). Geogaceta, 61, 27-30.

Rotevatn, A. \& Jackson, C. A. L. 2014. 3D structure and evolution of folds during normal fault dip linkage. Journal of the Geological Society, 171, 821-829. 
989

990

991

992

993

994

995

996

997

998

999

1000

1001

1002

1003

1004

1005

1006

1007

1008

1009

1010

1011

1012

1013

1014

1015

1016

1017

1018

1019

1020

1021

1022

1023

1024

Sánchez-García, T., Quesada, C., Bellido, F., Dunning, G. \& González de Tanago, J. 2008. Two-step magma flooding of the upper crust during rifting: the Early Paleozoic of the Ossa-Morena zone (SW Iberia). Tectonophysics, 461, 72-90.

Sánchez-García, T., Chichorro, M., Solá, R., Álvaro, J. J., Quesada, C., \& Díez Montes, A. (in press). Rifting stage. In: Quesada, C. \& Oliveira, J. T. (eds.) The Geology of Iberia: a Geodynamic Approach. Regional Geology Reviews Series. Springer, Heidelberg.

Santanach, P. 1972. Sobre una discordancia en el Paleozoico inferior de los Pirineos orientales. Acta Geológica Hispánica, 7, 129-132.

Sánz-López, J. \& Sarmiento, G. N. 1995. Asociaciones de conodontos del Ashgill y Llandovery en horizontes carbonatados del Valle del Freser (Girona). XI Jornadas de Paleontología, Tremp, 157-160.

Sanz-López, J., Gil-Peña, I. \& Valenzuela-Ríos, J. I. 2002. Lower Palaeozoic rocks from the Pyrenees: A synthesis. In: García-López, S. \& Bastida, F. (eds.) Palaeozoic Conodonts from Northern Spain. 8th International Conodont Symposium held in Europe, 1, 349365. Serie Cuadernos del Museo Geominero (IGME), Madrid.

Sanz-López, J., Perret M. F. \& Vachard, D. 2006. Silurian to Mississipian series of the eastern Catalan Pyrenees (Spain), updated by conodonts, foraminifers and algae. Geobios, 39, 709-725.

Sharp, I. R., Gawthorpe, R. L., Underhill, J. R. \& Gupta, S. 2000. Fault-propagation folding in extensional settings: Examples of structural style and synrift sedimentary response from the Suez rift, Sinai, Egypt. Geological Society of America Bulletin, 112, 1877-1899.

Speksnijder, A. 1986. Geological analysis of Paleozoic large-scale faulting in the south-central Pyrenees. Geologica Ultraiectina, 43, 1-211.

Stampfli, G. M., von Raumer, J. F. \& Borel, G. D. 2002. Paleozoic evolution of pre-Variscan terranes: from Gondwana to the Variscan collision. In: Martínez Catalán, J. R., Hatcher, R. D., Arenas, R. \& García, F. D. (eds.) Variscan-Appalachian Dynamics: the Building of the Late Paleozoic Basement. Geological Society of America ed., Boulder, 263-280. 
1025

1026

1027

1028

1029

1030

1031

1032

1033

1034

1035

1036

1037

1038

1039

1040

1041

1042

1043

1044

1045

1046

1047

1048

1049

1050

1051

1052

1053

1054

1055

1056

1057

1058

1059

1060

1061

Stille, H. 1939. Bemerkungen betreffend die "Sardische" Faultung und den Ausdruck "Ophiolitisch”. Zeitschrift der Deutschen Gessellschaft für Geowissenschaften, 91, 771773.

Štorch, P., Roqué Bernal, J. \& Gutiérrez-Marco, J. C. 2018. A graptolite-rich Ordovician-Silurian boundary section in the south-central Pyrenees, Spain: stratigraphical and palaeobiogeographical Gignificance. Geological Magazine, doi:10.1017/S001675681800047X.

Teichmüller, R. 1931. Zur Geologie des Thyrrhenisgebietes. Teil 1: Alte und junge Krustenbewegungen im südlichen Sardinien. Abhandlungen von der Gesellschaft der Wissenschaften zu Göttingen. Mathematisch-Physikalische Klasse, 3, 857-950.

Thompsom, M. D., Grunow, A. M. \& Ramezani, J. 2010. Cambro-Ordovician paleogeography of the Southeastern New England Avalon Zone: Implications for Gondwana breakup. Geological Society of America Bulletin, 122, 76-88.

Torsvik, T. H., \& Cocks, L. R. M. 2004. Earth geography from 400 to 250 Ma: a palaeomagnetic, faunal and facies review. Journal of the Geological Society, 161, 555-572.

Torsvik, T. H., \& Cocks, L. R. M. 2009. The Lower Palaeozoic palaeogeographical evolution of the northeastern and eastern peri-Gondwanan margin from Turkey to New Zealand. In: Basset, M. G. (Ed.), Early Palaeozoic Peri-Gondwana Terranes: New Insights from Tectonics to Biogeography. Geological Society, London, Special Publications, 325, 321.

Turner, F. J. \& Weiss, L. E. 1963. Structural Analysis of Metamorphic Tectonites. Mac Graw-Hill, New Cork.

Von Raumer, J. F. \& Stampfli, G. M. 2008. The birth of the Rheic Ocean - early Palaeozoic subsidence patterns and tectonic plate scenarios. Tectonophysics, 461, 9-20.

Xiao, H. \& Suppe, J. 1992. Origin of rollover. American Association of Petroleum Geologists Bulletin, 76, 509-529.

Zwart, H. J. 1979. The Geology of the Central Pyrenees. Leidse Geologische Mededelingen, $50,1-74$. 
1062

1063

1064

1065

1066

1067

1068

1069

1070

1071

1072

1073

1074

1075

1076

1077

1078

1079

1080

1081

1082

1083

1084

1085

1086

1087

1088

1089

1090

1091

1092

1093

1094

1095

1096

1097

1098

\section{FIGURE CAPTIONS}

Fig. 1. Geologic sketch of the Eastern Pyrenees with the location of the study area.

Fig. 2. (a) Detailed geologic map of the study area. (b) Geological cross-section of the study area. Location on Fig. 1.

Fig. 3. Cambrian-Ordovician and Upper Ordovician stratigraphic log measured near Ordén (top at GSP point). Location on Fig. 2. 1) shales; 2) siltstones; 3) sandstones; 4) conglomerates; 5) quartzites; 6) marlstones; 7) fossils; 8) ripples; 9) plane lamination; 10) bioturbation.

Fig. 4. Examples of the Upper Ordovician unconformity in the study area. UO, Upper Ordovician; CO, Cambrian-Ordovician. Angular unconformity, $78^{\circ}$ (a), 69 ${ }^{\circ}$ (b), and $34^{\circ}$ (c) respectively. Location on Fig. 2.

Fig. 5. (a) 3D representation of the study area with estimation of the orientation of the unconformity surface and the extensional faults; (b) equal area lower hemisphere stereoplot of the unconformity and (c) equal area lower hemisphere stereoplot of extensional faults from cartographic data using MOVE software.

Fig. 6. (a), (b), (c), (d), (e) and (f) Equal area lower hemisphere stereoplots of the disposition of the Upper Ordovician bedding surfaces in the six domains (D1, D2, D3, D4, D5 and D6) individuated from west to east between the extensional faults. The Upper Ordovician unconformity surface is shown (red dashed line) in the stereoplots together with the average bedding planes (black lines) in (a, b, c, d), or the best-fit girdle (blue line) in (e) and (f). $n$ indicates the number of measurements.

Fig. 7. Equal area lower hemisphere stereoplots of bedding $\left(S_{0}\right), D_{2}$ related mesostructures $\left(S_{2}\right.$ cleavage and $L_{0-2}$ intersection lineation), and $D_{3}$ related mesostructures $\left(S_{3}\right.$ cleavage and $L_{0-3}$ intersection lineation) from the Cambrian-Ordovician (a, c and e) and Upper Ordovician successions (b, $\mathbf{d}$ and $\mathbf{f}$ ) in the study area. In (c) and (d), the $\mathrm{L}_{0-2}$ intersection lineations are distributed along a great circle that is coincident with the $S_{2}$ average plane (in green) and in (e) and (f) the $\mathrm{L}_{0-3}$ intersection lineations are distributed along a great circle that is coincident with the $S_{3}$ average plane (in red). $n$ indicates the number of measurements.

Fig. 8. (a) Sketch and equal area lower hemisphere stereoplot of the Upper Ordovician unconformity (83/033) overlying Cambrian-Ordovician subvertical beds (296/77 and 178/86); 
1099 (b) disposition of the Cambrian-Ordovician beds after a ca. 90 rotation about a horizontal axis

1100 parallel to the unconformity (00/123).

1102 Fig. 9. (a), (b), (c) and (d), detailed sketches showing the disposition of $\mathrm{S}_{0}$ bedding planes in the Cambrian-Ordovician rocks. Inset, location of the different zones.

Fig. 10. Breccia levels of the Rabassa Conglomerate Formation neighbouring synsedimentary normal faults at La Molina. (a) Clast-supported angular cobbles of sandstone and shale (derived from the underlying Jujols Group) mixed with hydrothermal quartz clasts sourced from synsedimentary veins (arrowed). (b) Thin-section photomicrograph of previous sample showing reworked hydrothermal polycrystalline quartz (pQ), siltstone (s), claystone (cl) and mafic phenocryst $(\mathrm{v})$ clasts embedded in an unsorted sandy-to-clayey matrix; scale $=1 \mathrm{~mm}$.

Fig. 11. (a) Sardic angular discordance separating the Jujols shales (left) from the Rabassa breccia deposits (right) at Talltendre. (b) Subvertical dyke of hydrothermal quartz representing a synsedimentary fault marking the Jujols/Rabassa contact at La Molina; scale $=10 \mathrm{~cm}$. (c) Folded dykes of hydrothermal quartz encased in the Jujols shale neighbouring a synsedimentary normal fault that separates it from the Rabassa Formation at Talltendre. (d)

1117 Basal part of the Rabassa Formation close to the unconformity of Figure 11a, showing a breccia 1118 of clast-supported polymictic blocks rich in shales and sandstones of the underlying Jujols

1119 Group and hydrothermal quartz clasts sourced from the dykes (arrowed) that crosscut the outcrop at Talltendre. (e) Matrix-supported breccia of the Rabassa Formation with folded dykes of hydrothermal quartz (arrowed) at Talltendre. (f) Typical clast-supported polymictic conglomerate of the Rabassa Formation at La Molina. (g) Amalgamated trough cross-stratified sets of a lenticular sandstone package, up to $2.2 \mathrm{~m}$ thick and $8 \mathrm{~m}$ of lateral continuity, embedded in shales; lower part of Cava Formation at Talltendre.

1126 Fig. 12. Relative probability plot of the geochronological ages (U-Pb on zircon) of the 1127 Ordovician magmatism of the Pyrenees. Data after Deloule et al. (2002), Cocherie et al. (2005), 1128 Castiñeiras et al. (2008), Denèle et al. (2009), Casas et al. (2010), Liesa et al. (2011), Martínez et al. (2011), Mezger \& Gerdes (2016), Navidad et al. (2018) and Liesa et al. (unpublish.); n=25

Fig. 13. Sketch showing the geodynamic evolution described in the text (not to scale). 
Josep Maria Casas i Tuset

Dept. de Dinàmica de la Terra i de l'Oceà

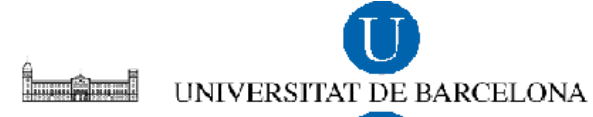

B

Dear Editor,

Barcelona, June 13th 2019

We submit the revised version of the manuscript: "Deciphering the Sardic (Ordovician) and Variscan deformations in the Eastern Pyrenees, SW Europe" that we would like to publish in your journal. We would like to acknowledge the two reviewers for their detailed work and constructive criticisms. We have incorporated most of their suggestions, which we feel has significantly improved the manuscript. We hope that with all the incorporated changes (in red in the manuscript) this contribution will be now suitable for publication in the your journal.

We have incorporated the formal suggestions and the comments of the reviewer\#1 about shortening the text. Some reorganizations of the text have also been done to avoid repetitions. Discussion chapter have been reorganized. Also we enlarged Conclusions chapter and the structural domains defined in the study area have been renamed.

We have also acted positively on most of the comments of reviewer\#2 concerning the text and the figures. However, there are some points in which our opinion differs form that of the reviewer. The changes introduced are detailed below together with some responses to their suggestions:

\section{ABSTRACT}

As the work talks about the Paleozoic rocks and Variscan deformation of the Pyrenees, the Axial Zone should be named in the abstract and described in the introduction or geological setting. It is mentioned in line 531 for first (and unique) time.

Revision: No, because the Axial Zone refers to the Alpine structure of the Pyrenees, not the Variscan one. In line 531 we are talking about the "Axial Zone" of the Montagne Noire.

Line 20: Say better "The Jujols Group", instead "Cambrian-Lower Ordovician" to avoid repetitions, because is already said that the Cambrian-Ordovician rocks are the Jujols Group.

Revision: Done

INTRODUCTION

Lines 38-62 (first paragraph of the introduction) starts mentioning the deformation events of the pre-Variscan rocks. I recommend add cites here (line 41). However, then only describe 
the antecedents of the Ordovician deformation. As the text talks about the Variscan structure too in the text (D2 and D3), antecedents about that should be included in the text.

Revision: Done

Line 64: New structural data

Revision: We disagree because this would be repetitive.

Line 65: La Cerdanya should be localize on map of Fig. 1 and reference it on the text.

Revision: Done

Line 69: origin and meaning, instead of meaning and origin.

Revision: Done

GEOLOGICAL SETTING

More references to the figures to better follow the text, especially figs. 2 and 3.

Revision: Done

Line 77: The Orri thrust should be depicted in the maps.

Revision: No, because this thrust is not cropping out in the Eastern Pyrenees

Line 83: Show La Molina locality in maps.

Revision: Done

Line 84: Age instead of datum.

Revision: Done

Line 96: Include cite for the gap found in Sardinia.

Revision: Done

Line 105: I think is not necessary include the words "conglomerate" and "quartzite" because the formations are going to be described after.

Revision: No because they are the formal names of the formatins described

Line 120: I consider it is not necessary start the paragraph with "Moreover". It can start with "The presence of volcanics...".

Revision: Done

Line 134: Delete the comma after Zwart to homogenize the cites.

Revision: Done

Lines 133-155: Last paragraph of geological setting introduces main deformation in the studied area by previous authors. D3 seems to be the main deformation phase, but a better description for the D1-D2 citing previous authors should be done. Thus, restructure this paragraph for better understanding.

Revision: Done 
STRUCTURE

This section only should include structure description and observations made by the authors. However, in some cases, they also include interpretations (e.g. line 206, 213, 279, ...). Please, move all the interpretations to the discussion section and show better your own results, especially in subsections D1, D2 and D3 structures, and extensional faults. I also consider that in these subsections, the authors should better remark the vergency of the structures.

Revision: this chapter has been modified

Line 167: Delete ".". Add "software" after MOVE.

Revision: Done

Line 173: Reference fig. 3 too.

Revision: Done

Line 189: "trends" or "orientations" instead of "attitudes".

Revision: Done

Lines 194-195: It is confusing talk about cleavage surfaces before the descriptions in the next paragraphs.

Revision: Done

Line 230: I consider that the comment about the S2 deflection is obvious and unnecessary.

Revision: We disagree. No structuralists can find this comment necessary to follow the argument.

Line 256: Where the axe of this fold should be?

Revision: In some part in he middle of the Canigó massif, North of the study area

Line 280: "peter out" is informal. Use decrease, or other synonym.

Revision: Done

Line 298: Fig. 6e.

Revision: Done

DISCUSSION

Line 318: The discussion should be better introduced, with sentences presenting the interpretation of the deformation phases, and not in the description above.

Discussion section should be last section before Conclusions. However, there are three sections (Tectonically induced sedimentation; Origin of the Sardic unconformity, extensional faults and D1 folds; and Comparison with other neighbouring areas) that is not clear that are included inside the discussion, and they should, because authors compare with previous works.

Revision: Done, this chapter has been reordered

Line 327: Why Alpine? Cite references or explain it.

Revision: Deleted to avoid ambiguities. 
From line 329 talks about the unconformity in the subsection of "Age and significance of D1 folds" and it is confusing mixing both structures. Please, separate them. Also, in this paragraph (and other parts of the text) doubt words as "perhaps" or "seems be" are included. I recommend do not use them and use more consistent sentences.

Revision: Done

Lines 344-348: This sentence is too long and also some words are repeated (faults, as a result). Rewrite it to better understanding.

Revision: Done

Line 352: "As a result" again.

Revision: Done

Lines 338-366: This paragraph is difficult to follow. Maybe some sketches or more references to figures make it easier to understand.

Revision: This paragraph has been rewritten

Lines 386-390: There are some repetitions in this sentence and can be simplified. For example, it is said twice that $S 1$ is the main cleavage in the studied area and other massifs.

Revision: This paragraph has been rewritten

Line 408: As said above, it is not clear that this section is included or not in the discussion. And, in my opinion, it should.

Lines 416-428: This paragraph includes a very good description of the Rabassa conglomerates, however should be in the geological setting with the description of the units and not in the discussion.

Line 430: The beginning of this paragraph is confusing: Where are recognized the facies?

The "Rabassa fm." has to be mentioned there.

Revision: This chapter has been reorganized and repetitions avoided

Line 441: Interpretations of the Sardic unconformity and D1 folds are also in the first subsection of the discussion. It should be reorganized for better understanding. Lines 443-455: This paragraph seems a detailed introduction of next ones. It should be shorter, and not repeat ages that be cited below.

Revision: The chapter has been reorganized

Line 468: Affected or originated?

Revision: Done

Line 489: Maybe add a sentence about the Toledanian phase, that is in lines 554-556.

Revision: Done

Lines 505-510: This sentence is too long, should be separated in two shorter sentences to better understanding.

Revision: Done

Line 521: "Grabbens" instead of "granbens".

Revision: Done 
Lines 525-530: Cite references.

Revision: Done

Lines 539-541: Same, cites would help.

Revision: Done

Lines 547: Do not recommend start a paragraph by "As a result". It should be continuation of the previous because continues talking about the same.

Revision: Done

Lines 557-559: The Toledanian phase should be described the first time is mentioned.

Revision: Done

Lines 566-572: Long sentence.

Revision: Done

Lines 576-577: What the felsic and calc-alkaline magmatic rocks imply? Explain in a few of words.

Revision: This is explained in the lines below.

CONCLUSIONS

Line 591: It is better to be consistent and do not use doubt words as "may" (same in line 596). And "Ma" instead of "m.y."?

I suggest add a short paragraph (a couple of sentences) about the structure and deformation phases of the studied area because is it detailed on the text and appear in the title.

Revision: Done

ACKNOWLEDGEMENTS:

Line 611: Software packages/programs.

Revision: Done

FIGURES

1: Smooth the line of the thrust. Add more coordinates in the vertical axe. Line up the squares of the legend. Also add some localities I mention above.

Revision: Done

2: Line 1095: through? Add to the legend the blue thrust of the map and the dotted weave (NE of the map). Also add some localities I mention above.

Revision: Done

3: This stratigraphic column is very detailed for this work. I suggest to a simpler one. Moreover, all the data on the right side is unnecessary, and this legend is not explained. Is that all the Silurian thickness that there is in the area? If not, close with a discontinuous line.

Revision: The discontinuous line is added in gop of the Silurian and the figure captions enlarged to explain all the legend

4: Add in the figure caption "CO" and "UO". Is there creep in picture B? 
Revision: Done. No it is a visual effect probably.

5: Numbers in B and $C$ are very small. And also points, it is not easy to see. Line 1105-1106 "unconformity and normal faults surfaces; (b) stereographic projection of the unconformity, and (c) the extensional faults from cartographic data using MOVE software.

\section{Revision: Done}

6: What "1\%" means in the stereoplots? As is always the same value I recommend add the data to the figure caption. In comparison, too many measures in D5 domain. The map (that is the same that is in fig. 2) is very big in the figure. As the only new information is the domains, I suggest add them to fig. 2 and reference it. This figure would be smaller and simpler, with all the importance on the stereoplots.

\section{Revision: Done}

7: Same of fig. 6 about the 1\%, it is repetitive. Add to the legends of each stereoplot a dot with the foliations, to see that dots are S0/2/3 and the triangles are the lineations.

Revision: Done

8: I suggest not repeat the map again. If not, do it simpler: here, the topography in the inset is not necessary.

Revision: Done

10: Locate La Molina. Line 1136: "probably"?

Revision: Done. Deleted.

11: Locate La Molina. Line 1141: The Jujols/Rabassa contact is the unconformity. Line 1144: fig. 11A. Lines 1144-1147: Long sentence.

\section{Revision: Done}

12: It seems that there are too many publications for only 25 datations. Is it well? I suggest add a sentence to the figure caption with the isotops (U/Pb?) and mineral (zircons?).

Revision: Done

13: This figure is not very clear, and it is crucial for the text. Add all the colours to the legend (blue, dark green, red) even if it is obvious. $a, b, c)$ should be at the left of the sketches. Arrows are very big too. To make it easier, I recommend add other sketch between the magmatism and the end. It seems that there are a lot of subsidence.

Revision: Done. We don't consider necessary to add another sketch to the figure

Looking forward to hearing from you soon,

Yours sincerely,

Josep Maria Casas

Departament de Dinàmica de la Terra i de l'Oceà, Facultat de Ciències de la Terra, Universitat de Barcelona-Institut de recerca GEOMODELS, Martí i Franqués, s/n, 08028

Barcelona, Spain

Tel. $+(34) 934021388$ 
Fax +(34) 934021340

E-mail casas@ub.edu 


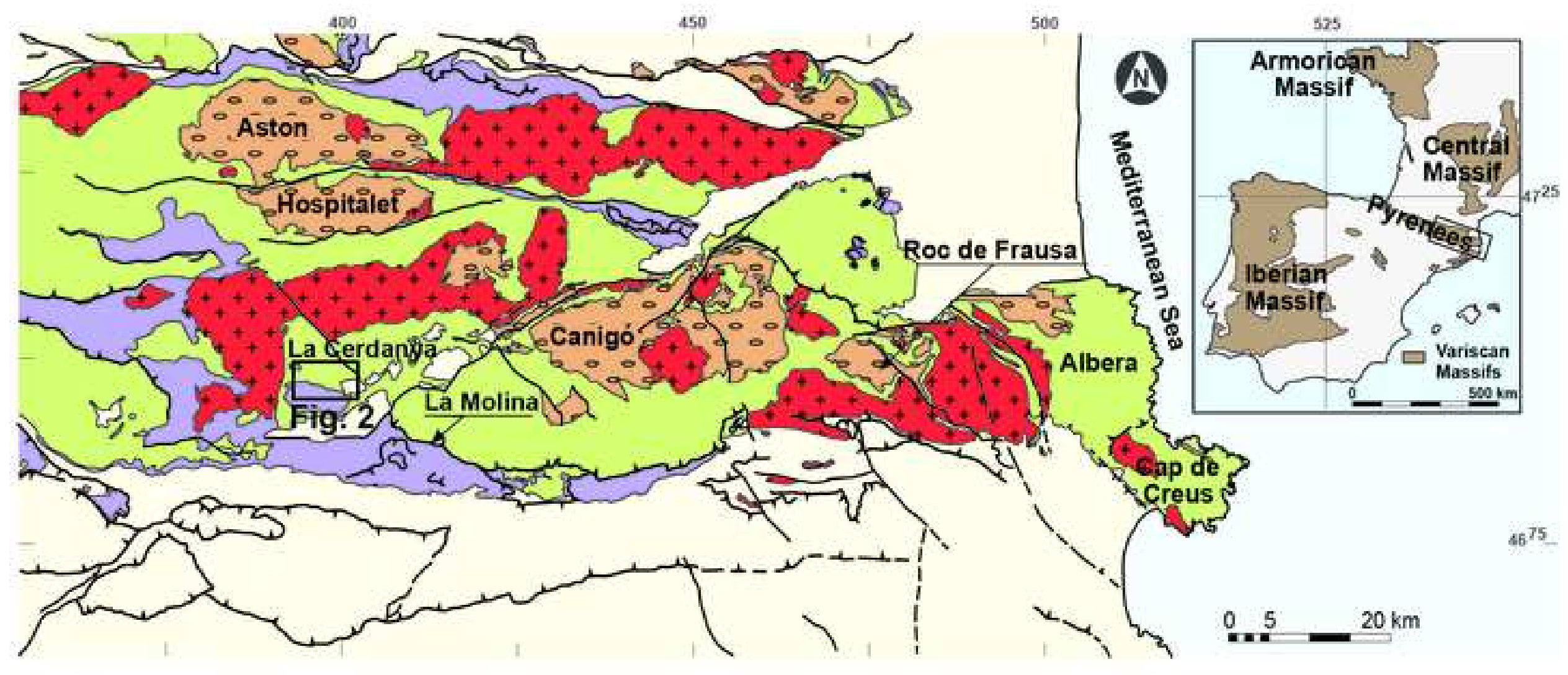

ए Post-Variscan formations

++ Variscan Granitoids

Silurian, Devonian and Carboniferous formations
[0. Gneisses (mainly Ordovician intrusives)

Upper Neoproterozoic and Cambrian-Ordovician formations
Thrust

Undifferentiated Fault 


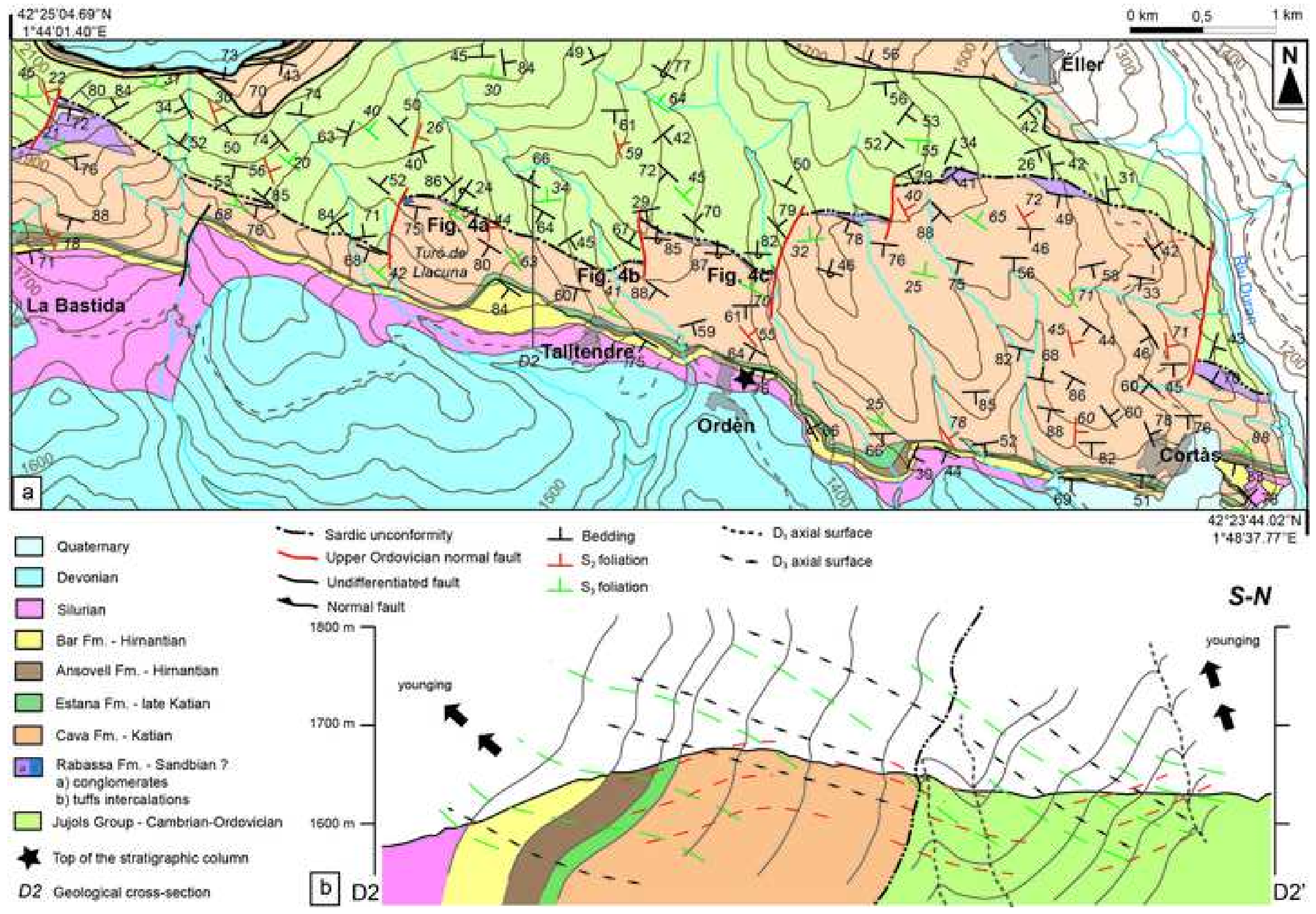




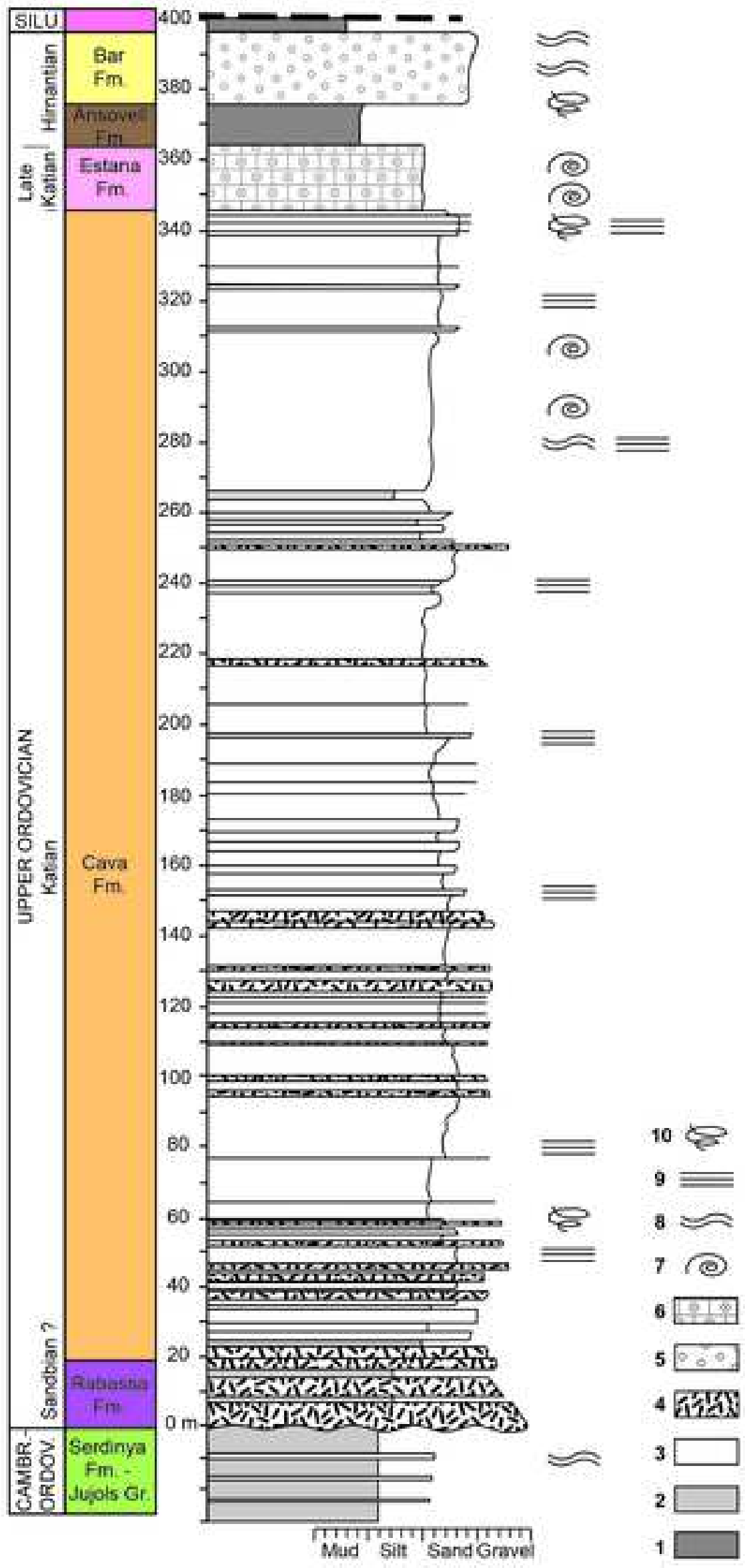




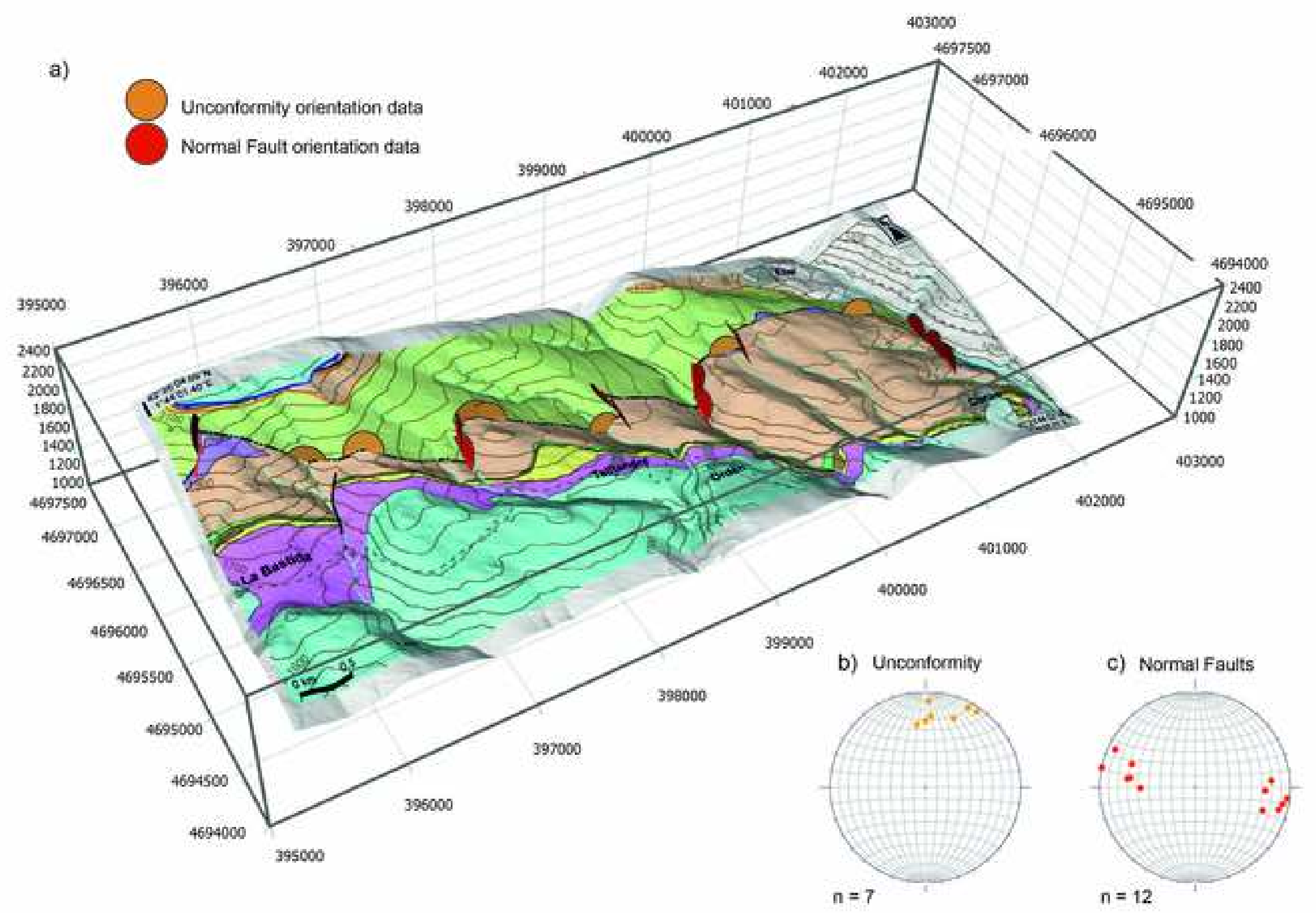




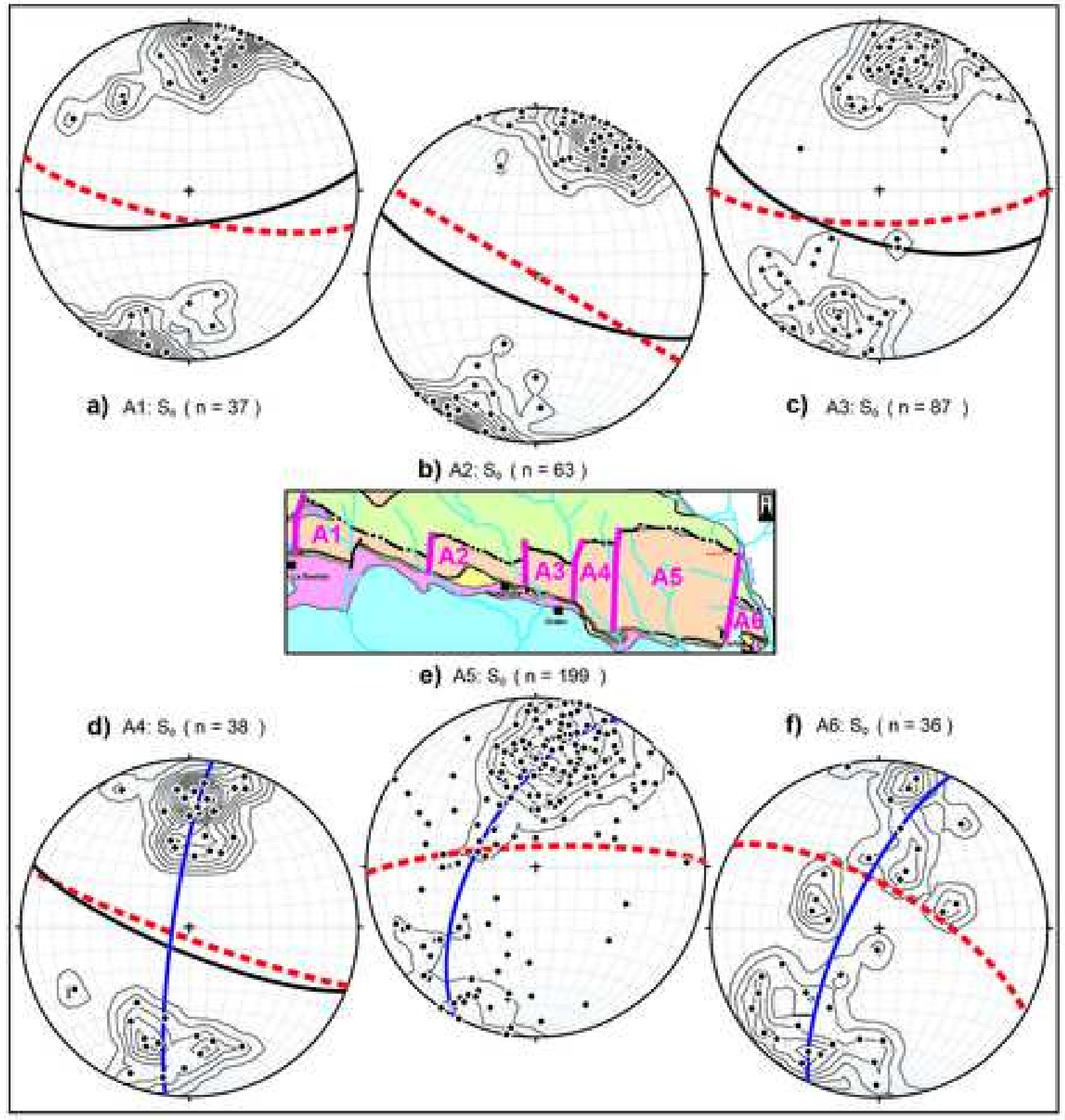




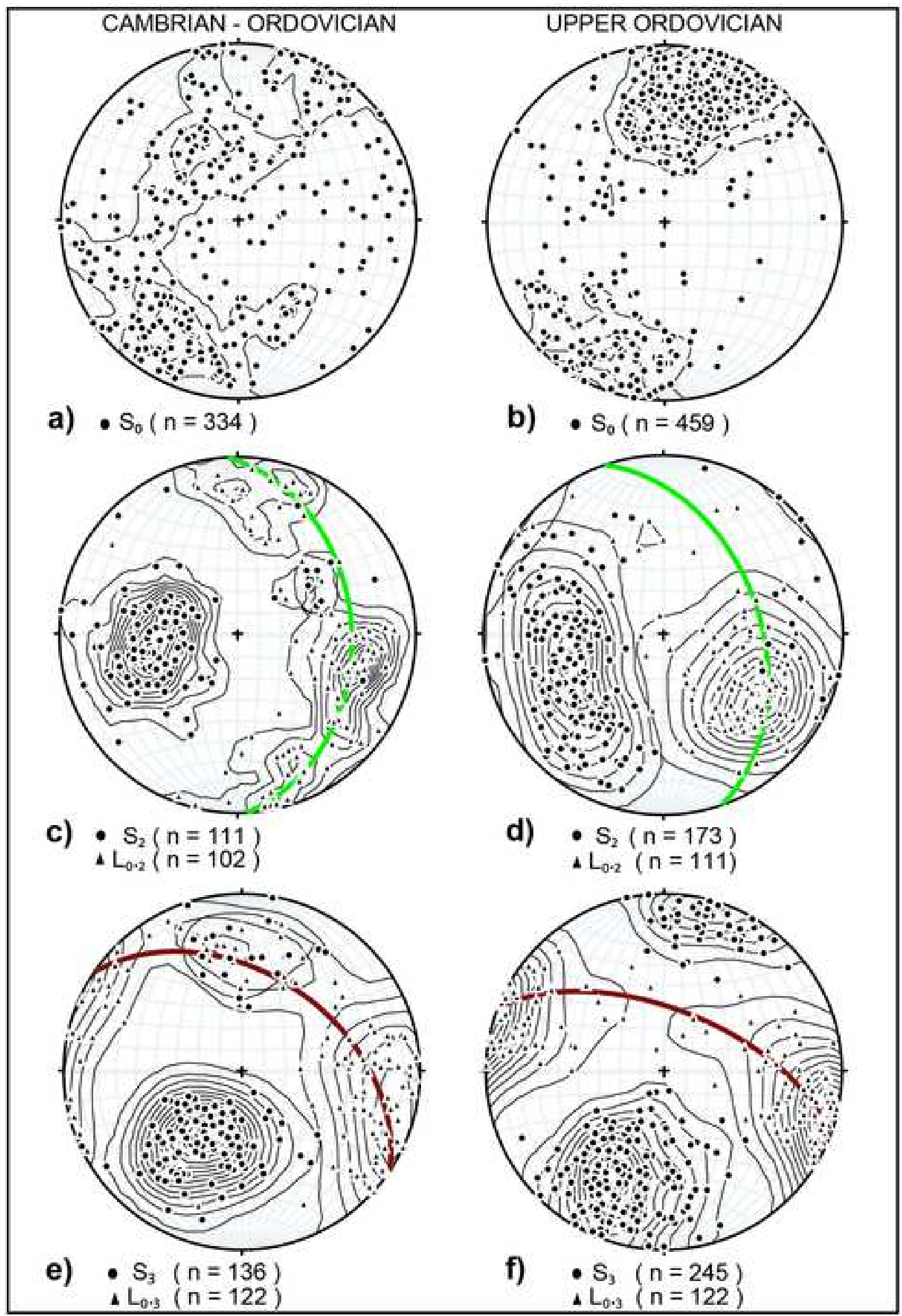



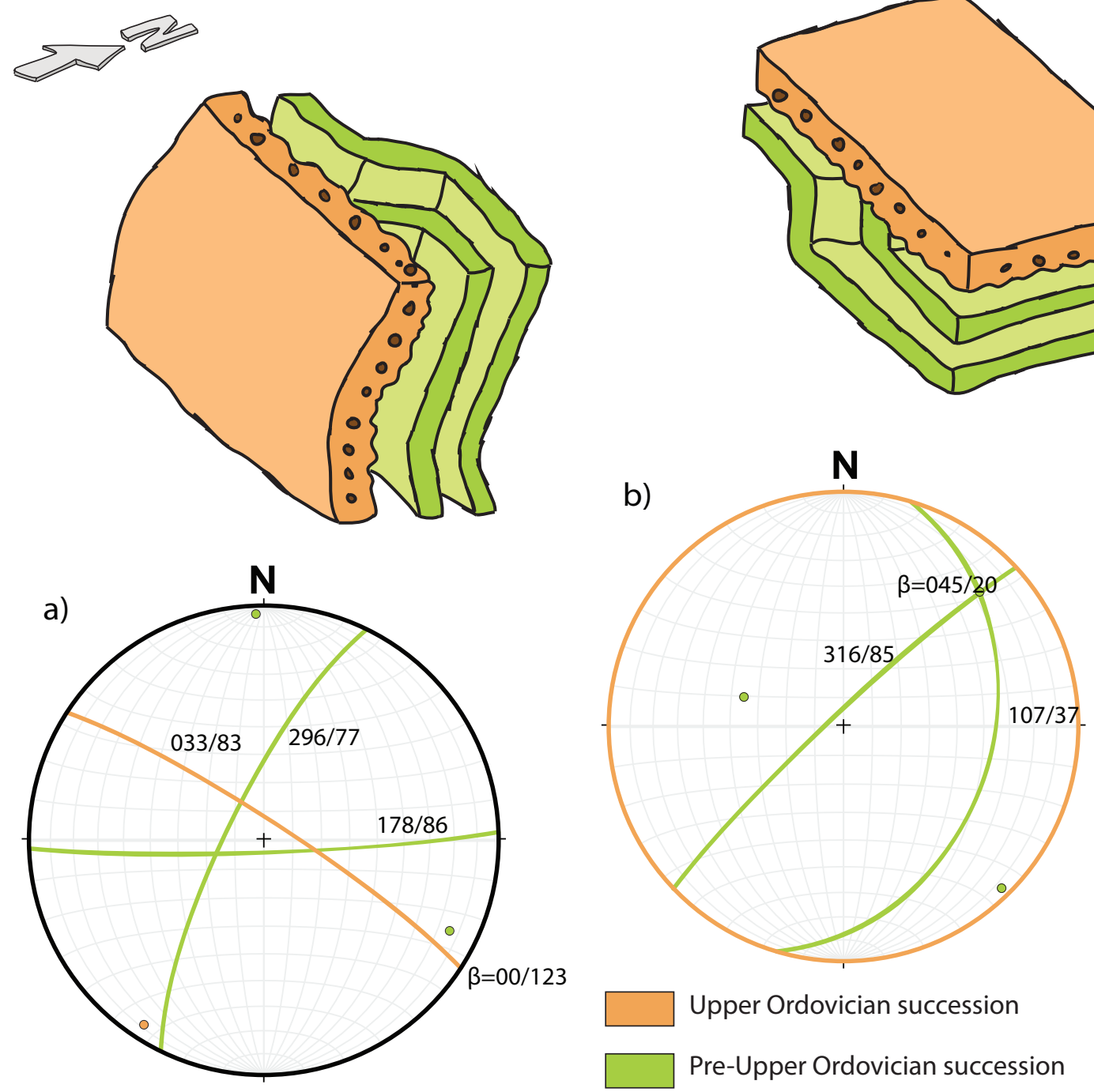


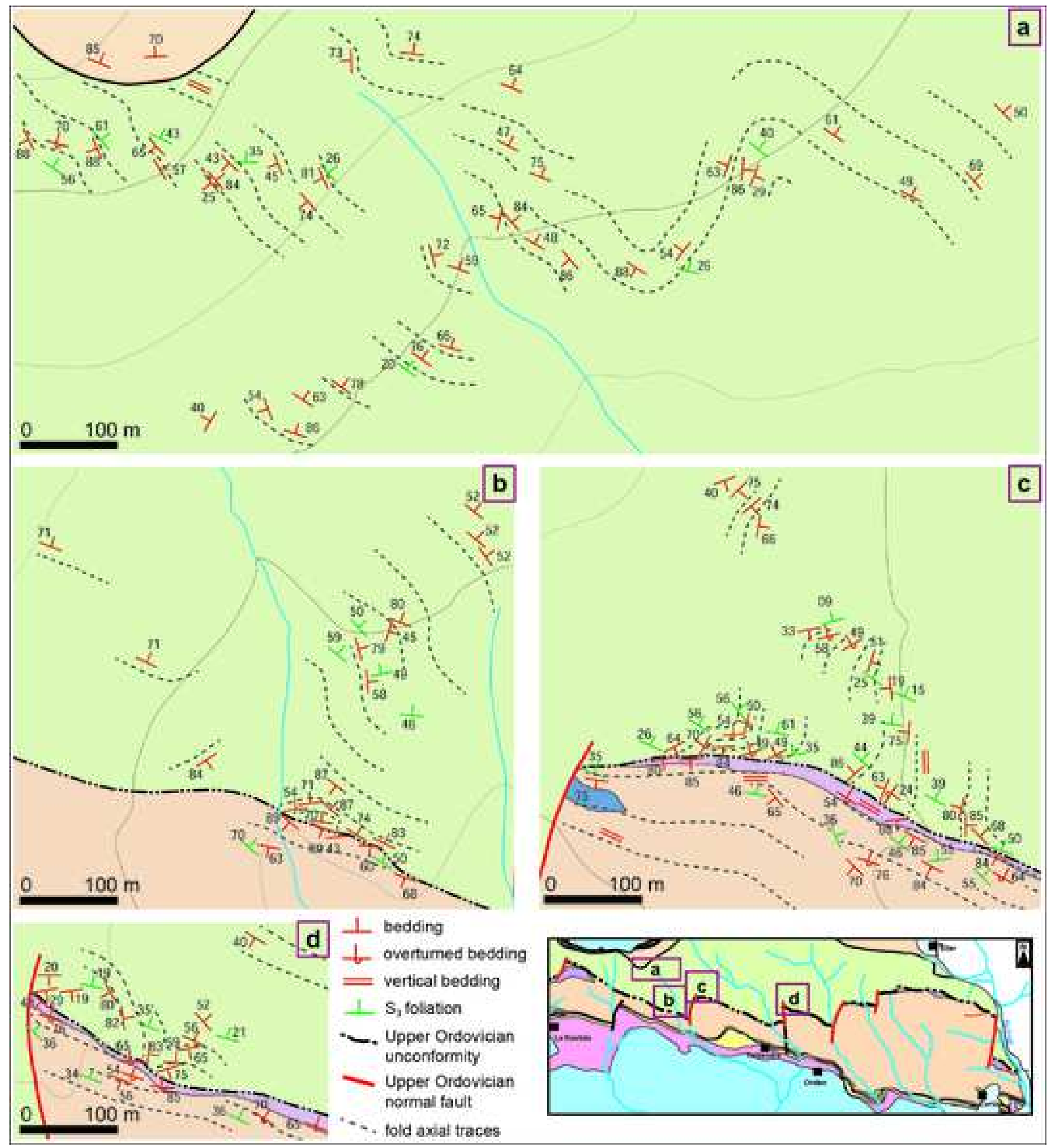



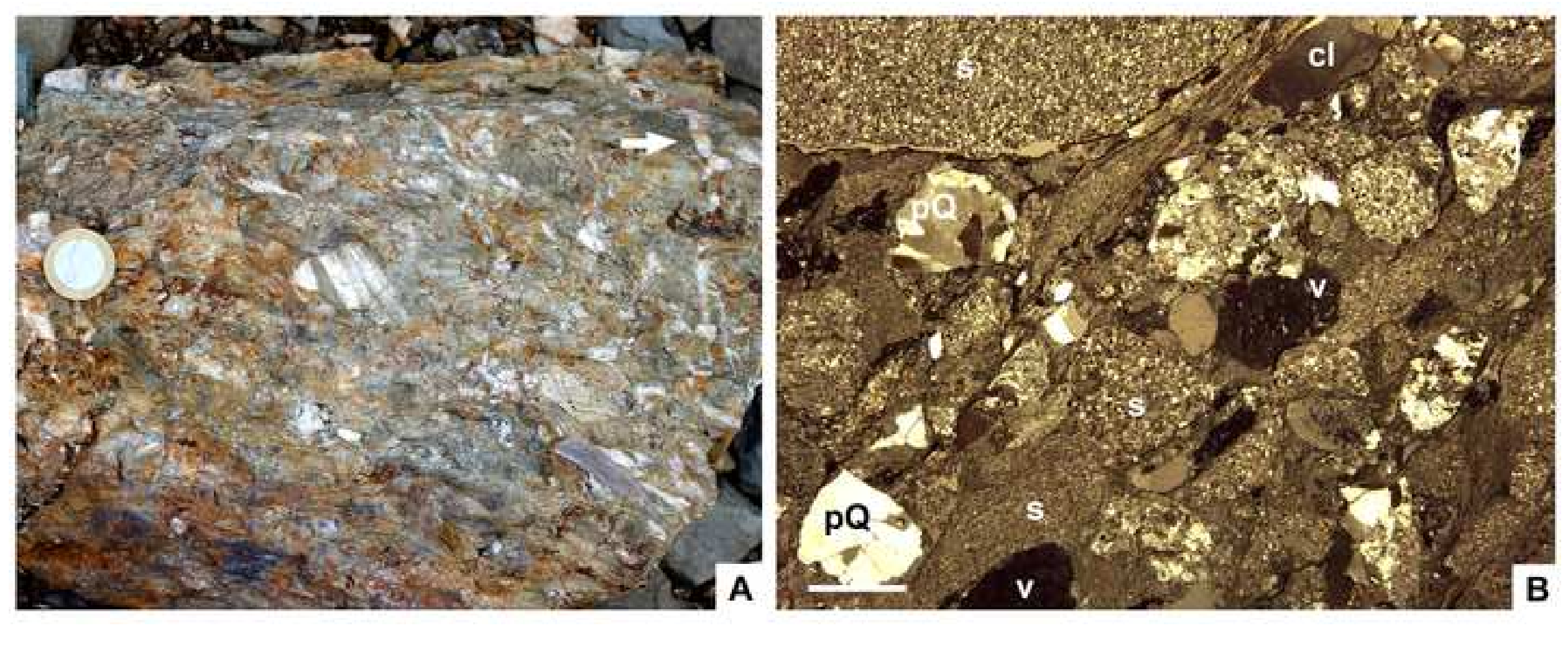

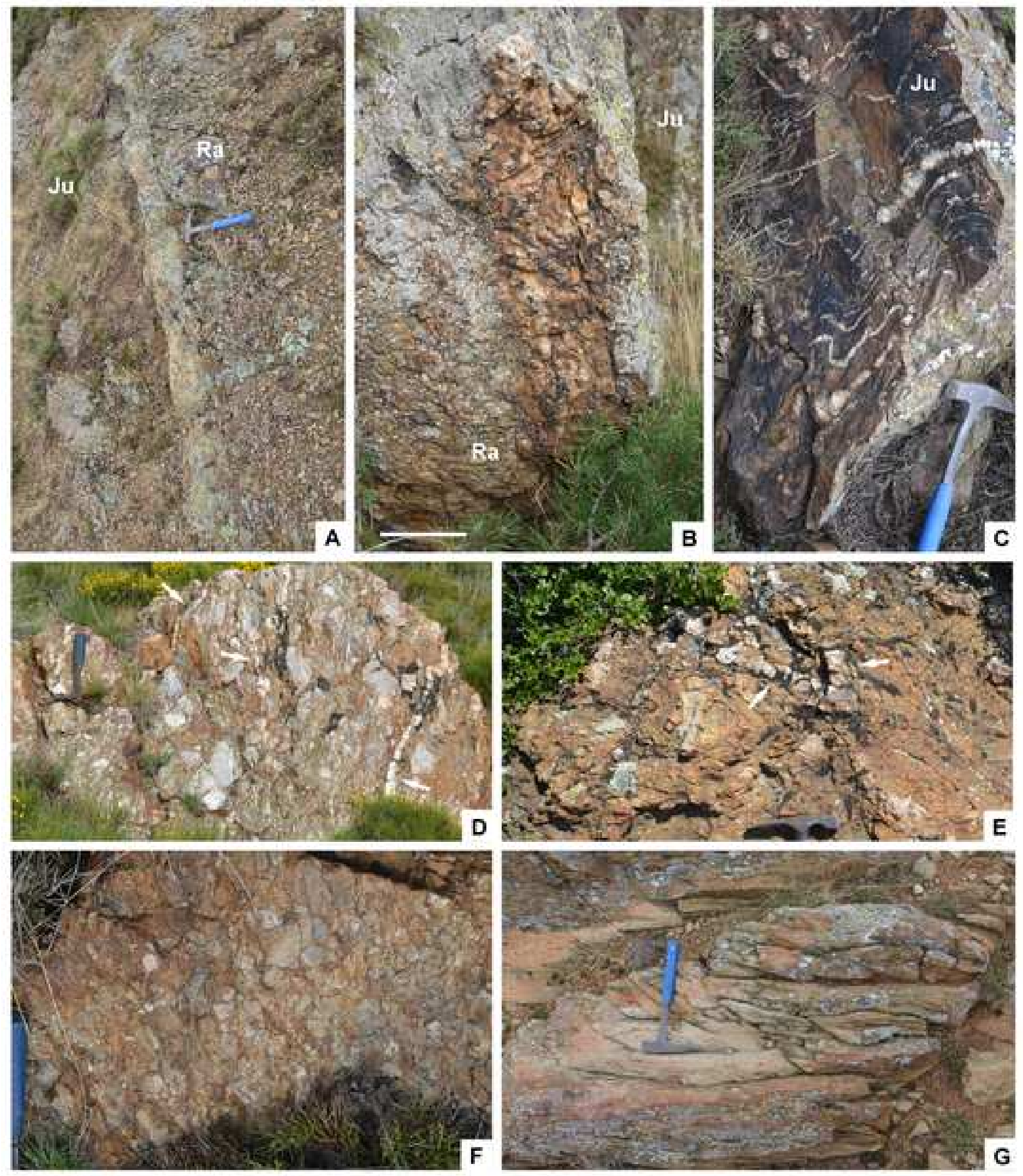


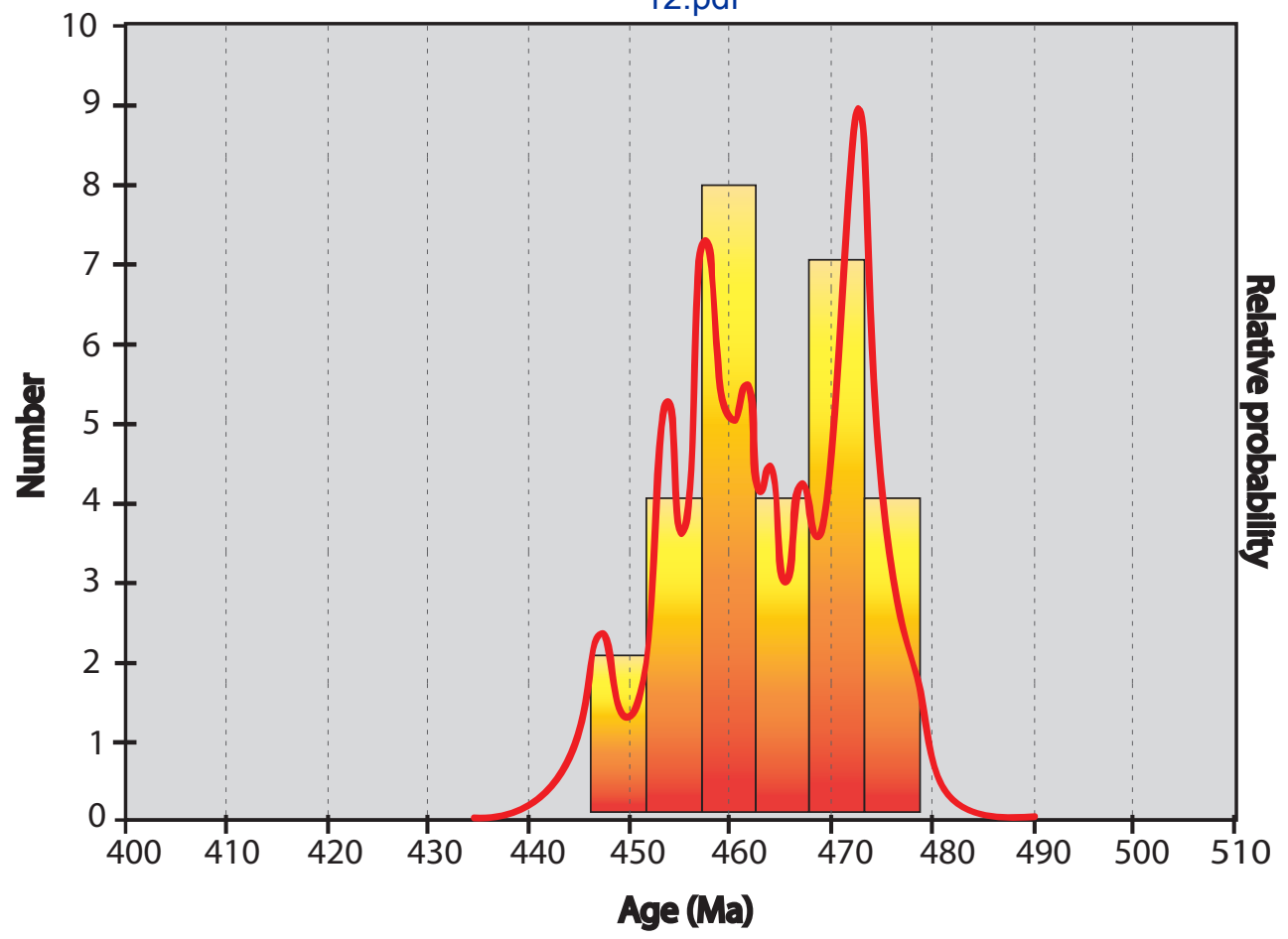


